\title{
Collusion or Collision? The War on Drugs in the Philippines
}

\author{
¿Colusión o colisión? La guerra contra las drogas en Filipinas \\ Colusão ou colisão? A guerra contra as drogas nas Filipinas
}

\author{
FRANCISCO J. LARA JR.* \\ NiKKI PhILLINE C. DE LA ROSA*
}

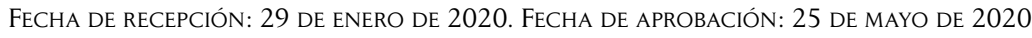

Doi: https://doi.org/10.12804/revistas.urosario.edu.co/sociojuridicos/a.9145

Para citar: Lara, F. J., E De la Rosa, N. P. (2020). Collusion or Collision? The War on Drugs in the Philippines. Estudios Socio-jurídicos, 22(2), 419-469. https://doi.org/10.12804/revistas.urosario.edu.co/sociojuridicos/a.9145

\begin{abstract}
The spiral of State-led violence against the illegal drug trade in Southeast Asia neither ended nor disrupted this shadow economy and its complex links to state and non-state actors as well as to the newly emerging violent extremism. The evidence in fact shows that the violent response to the problem has only fuelled more economic, political, and security concerns. This is the case in the Philippines where an indiscriminate and violent war on drugs has not lived up to its promises. Yet why is there continued public support for the anti-drug war despite its failures, particularly from among those who are often victimized by its violence? This paper takes an economic sociology approach to the problem of illegal drugs and turns the spotlight on the threats to embedded social networks posed by this deadly enterprise. Using quantitative and qualitative evidence and case studies from a province and city recognized as a hotbed in the government's anti-drug war, the study will show how collusion and collision are alternate realities and means of adapting to an illicit enterprise that is bound to many social and economic arrangements, including those brought about by violent extremism.
\end{abstract}

Keywords: Philippines drug war, illicit drug trade, populism, embedded social networks, violent extremism, violent conflict, economic sociology.

* Professor at the Department of Sociology, College of Social Sciences and Philosophy, University of the Philippines and Senior.

** Country Manager of International Alert Philippines. Email: ndelarosa@international-alert.org 


\section{RESUMEN}

La espiral de violencia dirigida por el Estado contra el tráfico ilegal de drogas en el sudeste asiático no terminó ni interrumpió esta economía sumergida y sus complejos vínculos con actores estatales y no estatales, así como con el nuevo extremismo violento emergente. De hecho, la evidencia muestra que la respuesta violenta al problema solo ha alimentado más preocupaciones económicas, políticas y de seguridad. Este es el caso de Filipinas, donde una guerra indiscriminada y violenta contra las drogas no ha cumplido sus promesas. Sin embargo, ¿por qué hay un continuo apoyo público para la guerra contra las drogas a pesar de sus fracasos, particularmente entre aquellos que a menudo son víctimas de su violencia? Este documento adopta un enfoque económicosociológico del problema de las drogas ilegales y pone de relieve las amenazas a las redes sociales integradas que plantea esta empresa mortal. Utilizando evidencia cuantitativa y cualitativa, y estudios de caso de una provincia y ciudad reconocida como un semillero en la guerra antidrogas del gobierno, el estudio mostrará cómo la colusión y la colisión son realidades alternativas y medios para adaptarse a una empresa ilícita que está vinculada a muchas actividades sociales y arreglos económicos, incluidos los provocados por el extremismo violento.

Palabras clave: guerra contra las drogas en Filipinas, tráfico ilícito de drogas, populismo, redes sociales integradas, extremismo violento, conflicto violento, sociología económica.

\section{RESUMO}

A espiral de violência dirigida pelo Estado contra o tráfico ilegal de drogas no sudeste asiático não terminou nem interrompeu esta economia paralela e seus complexos vínculos com atores estatais e não estatais, assim como com o novo extremismo violento emergente. De facto, a evidência mostra que a resposta violenta ao problema só tem alimentado mais preocupações económicas, políticas e de segurança. Este é o caso das Filipinas, onde uma guerra indiscriminada e violenta contra as drogas não tem cumprido suas promessas. No entanto, por quê há um contínuo apoio público para a guerra contra as drogas apesar de seus fracassos, particularmente entre aqueles que frequentemente são vítimas de sua violência? Este documento adota um enfoque econômico-sociológico do problema das drogas ilegais e destaca as ameaças às redes sociais integradas que apresenta esta empresa mortal. Utilizando evidência quantitativa e qualitativa e estudos de caso de uma província e cidade reconhecida como um celeiro na guerra antidrogas do governo, o estudo mostrará como a colusão e a colisão são realidades alternativas e meios para se adaptar a uma empresa ilícita que está vinculada a muitas atividades sociais e compromissos económicos, incluídos os provocados pelo extremismo violento.

Palavras-chave: guerra contra as drogas nas Filipinas, tráfico ilícito de drogas, populismo, redes sociais integradas, extremismo violento, conflito violento, sociologia económica. 


\section{Introduction}

Among the first steps that Philippine president Rodrigo Duterte took when he assumed power in 2016 was to wage a "war on drugs" in a manner that he promised would be unlike anything the country had seen in the past. ${ }^{1}$ In a region that has long endured the continued expansion of the illegal drug trade and the intense violence that came with it, the call to action by the Philippine president seemed to be untimely and out of touch with the growing body of evidence running against it. ${ }^{2}$

Before long, the war on drugs turned brutal and relentless, and the body count soared soon after it was launched. The chief of the Philippine National Police was clear and concise when he announced at the start of the campaign that the aim was to "neutralize the drug personalities nationwide". ${ }^{3}$ In contrast to previous campaigns, the new strategy certainly looked like a war, albeit a dirty one -employing extra-legal and extra-judicial actions that provoked a backlash from local and international human rights bodies and the local and international media-. The country's liberal and democratic standing within ASEAN and the United Nations suffered a major blow.

By 2018 the official body count had reached close to five thousand people within the country, and mostly in the national capital region (NCR). ${ }^{4}$

1 President Duterte declared a "war on drugs" in his first State of the Nation Address (SONA) on 25 July 2016 or soon after he was elected President in the May 2016 elections. More than a year later, Human Rights Watch reported that "Duterte's pursuit of his drug war despite international opprobrium and its skyrocketing death toll is dismaying but not surprising. Duterte's presidential electoral platform included lurid pledges of near-biblical scale extrajudicial violence and promises of mass killings of tens of thousands of 'criminals', whose bodies he would dump in Manila Bay" (Human Rights Watch, 7 September 2017).

2 There is a vast literature about the perils of a security-oriented and violent approach to the illegal drugs trade. In 2019 the International Drug Policy Consortium, a global network of 192 NGOs, declared that the objectives of the war on drugs "to eliminate or reduce significantly" the illicit cultivation, production, trafficking, sale and consumption of drugs have not been achieved and, in most cases, have caused added health, social, public security and economic harms" (International Drug Policy Consortium, 19 February 2019). See also Stoicescu and Lasco (2019) and Duffield (1998).

3 PNP Chief Rolando De la Rosa later retreated from his statement by saying that neutralization meant more arrests rather than death, despite the clear instructions of the President that he wanted to see dead drug lords and personalities (Philippine Daily Inquirer, 28 February 2017).

4 In the official report given to a press briefing by the Philippine National Police (PNP), the police reported a total of 98,799 police operations leading to the death of 4,251 drug 
In contrast, reports from human rights groups showed more than seven thousand suspects ( 7025 or about 35 persons a day) have been killed in what Amnesty International (2018) described as the extra-judicial killing (EJK) of persons suspected of being producers, traders, pushers, and users of narcotics. Worse, the unofficial body count from media showed even higher figures, that were closer to twelve to fifteen thousand. ${ }^{5}$

While the facts and statistics are contested and confusing, one important aspect of the war is not. The campaign has elicited wide public support within the country and from Filipinos living abroad. Polls and media reports indicate that support was widespread among different classes in Philippine society. ${ }^{6}$ Despite the limited success of the war in contrast to the rising human costs and the international backlash against the Philippines, the obvious truth was that people ignored the criticisms and few resisted the campaign's deadly onslaught.

Indeed, by 2018, or two years after the war on drugs was launched, it became clear that the results of the country's war on drugs was turning out to be no different than the anti-illicit drug campaigns undertaken in other countries. ${ }^{7}$ For starters, the new government's strategy was focused on the demand side of the drug problem, targeting street level pushers, protectors, and financiers that would eventually include drug users and the youth particularly within urban poor communities. Also, like other anti-drug wars, the impunity to kill turned the campaign into a war against human rights and international humanitarian law as well. ${ }^{8}$

personalities and the arrest of 142,069 others from July 1, 2016 to April 30, 2018 (Philippine Star, 8 May 2018).

5 Philippine security officials have contested the numbers, implying that the figures may have included deaths from the knock-on effects of the drug war, such as turf wars and revenge killings. (Reuters, 16 August 2017).

6 The Economist (2020) and Reuters (2017) both reported on the support of Duterte's war on drugs that cuts across all classes in the Philippines.

7 The war on drugs in Colombia and Thailand restored some peace and security for a while, similar to the Philippines case, and was popular to the public, but it did not stem the use and export of heroin, cocaine, and other illicit drugs and similarly brought the human rights situation to its knees. See Arsenault. Al Jazeera, 22 May 2014. Did Colombia's war on drugs succeed? See also The Conversation (29 September 2016).

8 The same severe, hard- line and mailed fist approaches were utilized in Cambodia, Indonesia, and Brazil. 
In terms of achievements, the Philippine Drug Enforcement Agency (PDEA), the highest level executive body leading the fight against illicit drugs in the country, reported in 2019 that despite its efforts, it was only able to seize one percent $(1 \%)$ of the total methamphetamine hydrochloride supply in the past three years - a reality not too far from similar experiences in other countries-?

These findings lead us to an important puzzle: why is there continuing public support for a war on drugs that has failed to deliver on its promises, and among people who are most affected by its violence?

There are at least two ways to address this conundrum: one way is to look at the manner in which the war was launched, assess its many weaknesses, and examine the hidden benefits and incentives that the Philippine government gets from pursuing a failed campaign. Another way is to analyse the contingent structures and social networks at the community level where support for the war on drugs and other illicit economies is rife, examine their rationale and incentives, and assess the distribution of power among and between these networks and the State.

This study focuses on the latter, and the reason is straightforward -it was clear from the outset that broad public support for the war on drugs was crucial and necessary for the State to continue its strategy regardless of what its performance was-. The research challenge was to explain how that support came about at the local level where it wields the most relevance and impact.

This study is important because it sheds light on the hidden forces and dynamics at the community level that determine the effectiveness and the level of support for the anti-drug war. It is also relevant because we need to disentangle the rhetoric from the real objectives of the anti-drug war in relation to the communities that are affected by it. Finally, the study is a timely contribution to the development of strategies and plans that can curb the potential resurgence of this illegal and deadly enterprise.

9 Vice president Leni Robredo reported in 2019 that the anti-drug campaign has been a dismal failure (see Philippine Star, 7 January 2020). Observers may argue that the Vice president Robredo is biased as a member of the legal opposition. However, she is not the only one that holds this view. See also UNODC report, March 2019. 
The study employs an economic sociology approach that looks at how the illicit drug economy is embedded in social networks that allow entrepreneurs in this illicit economy to generate huge profits, but at the same time constrains their choices due to existing social norms and controls that they need to reciprocate and uphold.

The concept of an "embedded" economy with both formal and substantive aspects is borrowed from Karl Polanyi (2011, pp. 4-11) and his studies of economic transactions that were mediated not simply by rational self-interest but also by reciprocity, redistribution, and exchange. In many instances, exchange arrangements in any market, including the market for illicit drugs, is affected by norms of reciprocity among producers, traders, and consumers, and the need to redistribute incomes and profits away from the centre and towards the peripheries.

Granovetter (2011, pp. 23-27) echoed Polanyi's notion of livelihoods being embedded in society when he enumerated various forms of socially oriented economic actions, including in those economies where malfeasance is managed by a system of "honour among thieves" (p. 29).

Portes (2010, p. 15) used the same lens when he argued that socially-oriented economic actions existed that lent importance to other "self-centred goals such as the quest for approval, status and power" besides profit and purely material gains, including "expectations of reciprocity".

Using the economic sociology approach thus requires an emphasis on the role of social arrangements and institutions in economic activities and outcomes, referred to as socially oriented economic actions in the literature, and used widely in studies of "network economies", as well as the broad range of informal and secondary economies in many poor and conflict-ridden areas (Meagher, 2010; Lara E Schoofs, 2016).

For example, some of the crucial social networks that are often neglected in the study of economic informality in the Philippines are the families and clans and the role they play in mediating transactions within the informal economies of Muslim Mindanao. Another important social network are the tricycle operators and drivers associations (TODA) that proliferate in the many enclaves of Metro-Manila and function as closely knit groups engaged in retail logistics and who possess their own 
set of rules and sanctions. ${ }^{10}$ We shall return to these important social networks later in this paper.

The study examines the institutional systems and dynamics that underlie other social structures bound by tribal, ethnic, and political identities. More importantly, the study examines the rival economies that thrive alongside the illegal drug economy, determining which of these contribute to growth and are forces of economic development versus those that spur economic decline and social disorder.

The research methodology was guided by similar studies conducted by those who have explored the intersection between social networks and shadow economies, using qualitative research methods that have been used in other studies such as in-depth interviews, focus group discussions, and trialogues. ${ }^{11}$ The authors immersed themselves in an urban enclave in Metro-Manila that is known as an illicit economies hotspot, as well as in the Islamic City of Marawi that was under siege from extremist groups in 2017. The authors also interviewed key respondents and made use of transcripts from focus group discussions and in-depth interviews conducted in the case study areas, as well as secondary data from media and community reports.

Descriptive quantitative data was also secured through an analysis of back-end information of drug-related violent incidents contained in an eight-year panel dataset on violent conflict, particularly drug-related violence, in the Bangsamoro region of Muslim Mindanao. The authors are grateful to International Alert Philippines for allowing the use of this panel data. Finally, the study employed multi-level case studies of the social networks that underlie the shadow economies in illegal drugs and others within the Bangsamoro Autonomous Region of Muslim Mindanao

10 Tricycle operators and drivers associations (TODA) are the backbone of the retail transport system in many informal settlements across the Philippines. TODA is generally an acronym for the "transport operators and drivers associations" that operate across the country as a social network of drivers in jeepneys, buses, taxicabs, and even tricycles. The letter ' $\mathrm{T}$ ' in the acronym is sometimes changed to tricycle or taxi in some instances to better describe the social network's transport enterprise.

11 Trialogues are mediated conversations that are often used in studies where respondents are often covert and where trust is important at the outset. A third person joins the conversation to mediate, situate, and help explain the responses of the respondent to the interviewer (Lara \& De la Rosa, 2016, pp. 49-52). 
(BARRM) and the towns of Marawi in Lanao del Sur, and Datu Saudi Ampatuan in Maguindanao. ${ }^{12}$

\section{The literature on illicit drugs, social networks, and violent conflict}

There are at least three relevant but contending approaches that are central to the analysis of the relationship between the illicit drug economy and development; peace building; and state building and how people's perceptions shape and were shaped by the war on drugs.

The first approach examines the war on drugs from a state building perspective, and the valid fears about an illicit economy's negative effects on state capacity and resilience. The thesis is that the illegality of the drug economy induces the creation of spaces outside state control that will become perpetual sources of criminal violence and rebellion (Cornell, 2007, p. 213). These spaces become signifiers of state fragility when those who benefit from illicit enterprises actively undermine the state's capacity to deter other criminal agendas (Goodhand, 2005, p. 195). For example, in Mindanao, the trade in illicit drugs is often linked or accompanied by the manufacture and trade in illegal weapons, kidnap-for-ransom, and smuggling.

Reno (1999) warned about a "shadow state" that incentivized patronage politics and allowed politicians and government executives to strengthen private control and monopolize economic resources and accumulate wealth. Bayart et al. (1999) made the same arguments about a "felonious" government authority that turned public offices into money-making machines for private gain.

The logic is that citizens will throw their weight behind the State's efforts to fight rival sources of coercive power and will support efforts to

12 Following the successful plebiscite that enacted a Bangsamoro Organic Law in February 2019, a new Bangsamoro Autonomous Region in Muslim Mindanao or BARRM was established to replace the old ARMM and is now composed of the five provinces of Maguindanao, Lanao del Sur, Basilan, Sulu, and Tawi-Tawi, including the premier Islamic City of Marawi and Cotabato City. Marawi City is the capital of the province of Lanao del Sur (MindaNews, 11 February 2019). 
liquidate the threats to order and security that the illicit drugs enterprise poses. However, the appeal to state building objectives does not resonate equally in all areas of the Philippines, and has the weakest traction in the case study areas selected for this study, where people hardly pay any taxes, where local communities are the most conflict-ridden across the country, and where the domestic centre of the illicit drug trade operates.

State building agendas certainly lack traction in those places where tribal, ethnic, and religious identities have constantly fought the State to respect their desire for autonomy and self-determination, and at one point, even secession. There is also an impasse when the legitimacy and credibility of local authority is built along the non-payment of taxes and the existence of rival holders of the means of coercion (Lara, 2014, pp. 263-272).

In fact, the operations of some local government units in the Bangsamoro Autonomous Region of Muslim Mindanao (BARMM) are replicas of the criminalized states that Reno and Bayart spoke about. In a compendium of shadow economy studies in the Bangsamoro region, the issue of both narco-politics and rebel involvement in the drug economy figured prominently (Guiam \& Schoofs, 2016, pp. 135-142). A more recent report on violent conflict indicated as well how former rebels were now being supplanted by violent extremists who provide protection to drug lords (Conflict Alert, 2017, p. 17). ${ }^{13}$

The second approach interrogates the war on drugs through a prism of fear and anxiety and how these feelings are marshalled to mobilize wide popular support for a highly punitive war on drugs. Referred to as "penal populism" in the sociological literature, the concept is to mobilize fears and offer the promise of punitive action to gain traction within local communities and the broader society for the conduct of a violent war on drugs despite the enormous human costs.

The thesis of penal populism has been used to describe the constant negotiation between the distinct yet interrelated politics of anxiety and hope (Curato, 2016, pp. 92-93). The argument is that the war on drugs shapes and is shaped by the fears over loss of life and property that local citizens feel, and that this anxiety in turn constricts the space of

13 SunStar News, 25 September 2017. 
political discourse by invoking the tough language of war against drugs and criminality, while hope broadens the scope of what electoral politics can achieve through alternative methods that depart from the classic machine politics of Philippine elections. ${ }^{14}$

In this approach, the widespread support for the war on drugs and the enduring appeal of "total war" strategies, despite their limited effectiveness and their history of failure, rests on assumptions about how local communities view the risks and dangers from a prevalent drug economy in terms of their perceptions of the peace and order situation in their communities. Penal populism has also been used to explain how the mobilization of collective sentiments of fear and demands for punitive politics in the manner in which Philippine Rodrigo Duterte implemented his authoritarian "Davao model" justified the massive use of force (Thompson, 2016).

The thesis looks well and good, except for one important thing that is absent in this approach, i.e., a clear sense of agency and accountability, and an understanding that collective actions are contingent upon specific circumstances, so that what may provoke anxiety and cause hope among urban informal settlers may not necessarily work for indigenous groups, clans, and other traditional organizations.

Agency has been submerged under an amorphous and mechanical notion of "community" and "society" without any attempt to scrutinize the structure of authority and power that operates within that community. In short, it is unclear how perceptions of anxiety and hope evolved, who their proponents are, and who stands to benefit directly from the punitive actions that are taken against drug pushers and users. The effect is dangerously close to what the approach claims to avoid in the first place, i. e., instead of causing hope, the analysis paralyzes people with fear and anxiety and casts the blame on a distant and ineffective, elite-controlled State -in the same way that the instigator of the war on drugs described the central, elite-dominated State-.

14 Curato (2016) adds how employing the "vocabulary of fear, crisis and danger, the latter is animated by enactments of democratic agency among citizens who have been in the margins of politics for a long time". 
There is a third approach that looks at the illicit drug economy in the Philippines, and in other countries where anti-drug wars have been initiated, as nested in communities where various social networks and arrangements exist. These networks can become stronger or weaker or expand and constrict depending upon the motivations and strategies of various actors engaged in the many informal, unregulated, and secondary economies that are prevalent in poor and conflict affected areas.

The approach uses the social embeddedness framework in economic sociology noted earlier that highlights the role of traditional and embedded social networks in the assessment and management of risk. A good example is MacGaffey's (1991, pp. 60-61) study of how the drug trade in Zaire (now the Democratic Republic of Congo) relied on sapeurs or the network of ostentatious, yet unemployed and often violent youth in Brazzaville to bring drugs in and out of the country starting with marijuana before moving to cocaine. Meanwhile, the conflict scholar William Reno (2004, p. 610) also wrote about how the Igbo tribe in Nigeria and their clan lineage and dynamics that placed them in a "commanding position in the world heroin traffic". ${ }^{15}$ In the Philippines, studies about the illicit cattle-rustling economy showed how a network of "liangan" insurers offered a secondary insurance market for the theft or death of cattle under their protection (Lara, 2016, pp. 243-272).

In this approach, the mechanisms for social monitoring and control, punitive sanctions, and repressive violence are contingent upon the balance of power between the illicit drug networks, the State, and rival social networks in other shadow economies. This paper specifically examines the social networks embedded in other shadow economy activities that may have been affected or threatened by the deadly and illicit drug economy, particularly the impact of law enforcement campaigns, lockdowns, and the militarization of communities that the narcotics syndicates brought upon themselves and their operations, and the push back from rival networks that have been affected by these operations.

15 Meagher (2010, p. 27) decried the description of Igbo economic networks as having a propensity for criminality and economic un-governance as suggested by Reno and reinforced by other studies of dysfunctional cultural features. Instead she presents evidence that Igbo rule systems have undergone important shifts that were imposed upon them during the colonial and post-colonial era. 
Meanwhile, closer to the Bangsamoro region, studies have shown how the illicit drugs economy endangered the social networks in the cross-border and barter trade. This trade had enabled the mobilization of capital among civil services workers and public school teachers that made it possible for them to engage in barter trade and earn extra incomes to supplement their savings (Lara \& Schoofs, 2016, pp. 311-323; Villanueva, 2016, pp. 262-263).

Though most social networks are local in nature, those in the illegal drugs enterprise are structured for cross-country if not cross-continental reach. There are certainly some global social networks that "may have different aims and effects, but are often interconnected and share the same networked, adaptive, and expansive character" (Duffield, 2000, p. 72). These connections invite the sort of "post-modern" violent conflict spurred by such groups as the Asian triads and the Latin American drug cartels.

However, like the two earlier approaches outlined in this literature review, there are pitfalls to using a social network approach especially when similar studies have often painted social networks in the informal, unregulated, or underground economies as sites of criminality and destabilization that do not contribute to growth but, instead, entrench poverty, inequality, and greed (Meagher, 2010, pp. 2-3; Kaplan, 1994; Bayart, et al., 1999).

There is also a tendency, very similar to what happened when the social capital framework reasserted itself in the 1980s and 1990s, to treat social networks as the new panacea for understanding many aspects of the formal and informal economy. Scholars have pointed out that the proliferation of the "social network" concept in many studies "threatens to relegate it to status of an evocative metaphor, applied so loosely that it ceases to mean anything" (Nohria, 1992, p. 3; Meagher, 2010, p. 12; Cooper, 2001, p. 206).

Indeed, without linking social networks to the role of the State, or even to external political economy influences, the war on drugs may be treated as a simple problem of conflicts between social networks or the outcome of dysfunctional cultural systems. It is important to begin by explaining the role of the illicit drug economy in reshaping economic informality in the Philippines and the important social networks that 
played a role in their evolution. This is also the rationale for assessing social networks embedded in other shadow economies that may have been affected or threatened by the illicit drug economy.

\section{Robust public support despite meagre results}

Many observers have argued that the robust support for the war on drugs was made possible by a combination of clever narratives that Duterte deployed during the election campaign, and soon after he gained power, that trumped his opponents. Duterte began by turning the narrative from a war on drugs into a "war against criminals". This aimed to convince Filipinos that he was simply eradicating criminals and "to overlook the death toll so long as his government satisfied their individual economic and political interests". ${ }^{16}$

The same ploy was highlighted by conflict analysts who noted how Duterte used the anti-drug campaign to blame drug pushers and users as people destroying their communities and then presenting himself as "an outsider fighting the 'Manila establishment and ineffective central government" (Putzel, 2016). Others promoted a story of collusion between drug lords and the country's elite, pointing to Duterte as "an illiberal populist who mobilised a mass constituency through the media (particularly social media) with the use of radical rhetoric portraying a corrupt elite that coddles drug dealers and addicts" (Thompson, 2016).

To be sure, the war against drugs did not spared neither the central state nor the local government units where drugs proliferate, as more than five hundred (504) government employees were arrested, including 217 locally elected officials in the first year alone. However, the big drug lords operating at the national and subnational level, including their police and military protectors were not as vulnerable. Many went into hiding and only a few were arrested or even prosecuted. Few attempts were made to disrupt the deadly links between the big drug lords operating

16 The Washington Post (23 October 2019) reports that while he was on the campaign trail, Duterte diagnosed drugs as the scourge of society, claiming that the use of drugs was connected with rape and murder. 
within the country and their criminal co-conspirators at the regional and international levels. ${ }^{17}$

To date the number of people that have been killed would rival the number of persons executed in the past decade due to the mandatory death penalties for drug trafficking institutionalized across many countries in Southeast Asia and China. Indeed, the 3,940 people who were executed globally, half of which were in Asia, pales in comparison to the numbers of people killed in one anti-drug war after another in the region.

For example, in the Philippines around 6,600 died in anti-drug operations between July $1^{\circ}, 2016$, the start of the Duterte administration, and May 31, 2019 as reported by PNP on Jun 2019.18 Opposition senators believe that more have been killed and estimate that at least 20,000 deaths are directly the result of the war on drugs. ${ }^{19}$ Thailand's anti-drug war led to at least 2,500 casualties in 2003, where at least 1,400 people were killed and labelled as drug suspects even though they had no link to drugs. ${ }^{20}$

These data explain why other studies have referred to these anti-drug wars as an "act of genocide". In one study of the anti-drug casualties in the Philippines, data harvested from news articles, policy issuances, government briefings, public speeches and drug-related statistics showed that the rhetoric and policies of the Duterte administration satisfied the step-by-step genocide processes of "classification, symbolization, dehumanization, organization, polarization, preparation, extermination and denial" (Simangan, 2017).

The war on drugs was a fulcrum in Duterte's campaign for the Presidency, claiming that the country was slowly turning into a narco-state and the youth were being turned into drug-crazed zombies. But unlike the other presidents before him, Duterte's strongman credentials provided a credible threat about the violent consequences for those opposed to the anti-drug campaign. For many years he had done the same "cleansing"

17 A Supreme Court hearing concluded that most of the victims in the anti-drug war were street level pushers and users, rather than the big drug lords (The Manila Times, $1^{\circ}$ May 2018).
18 ABS-CBN News, 18 June 2019.
19 Rappler, 21 February 2018
20 The Nation, $1^{\circ}$ February 2008. 
of the illicit drug trade when he was chief executive for close to two decades of Davao City -the largest urban centre in the southern Philippines-. Duterte was not averse to using coarse language to express his beliefs and to use violence openly and intensively in Davao City to rid the town of its drug scourge $-\mathrm{a}$ feat that sustained his strongman and populist politics over several electoral cycles in the city-.

Just as he did in Davao, Duterte was initially able to generate support for the war on drugs from a broader public weary about their children being addicted or their communities becoming centres of narcotic production and trade, and sites of crime and violence that accompanied the drug trade. Support for the anti-drug war was recorded by credible polling firms in the Philippines to be as high as $88 \%$ in 2017 going down only slightly to $82 \%$ in 2019. In turn, Duterte's approval and trust ratings also soared and has remained at very high levels - a feat unseen at any time in the country's past-. ${ }^{21}$

After the first eight months the effect on the people's sense of enhanced security and protection was palpable but unexpected, particularly by the big politicians and civil society groups that denounced Duterte's tactics before and after his rise to power. Repeated surveys confirmed this perception of improved security. The Social Weather Station (sws) $4^{\text {th }}$ quarter survey showed that $73 \%$ of Filipinos saw the falling number of illegal drug users since PRRD took office. ${ }^{22}$ The return on investments in violence surely paid off in terms of contributing towards the enduring popularity of Duterte as he heads toward the end of his term. However, the outcomes have been found wanting when it comes to countering and ending the illegal drug trade.

21 The report comes out of one of two survey firms with high credibility in the Philippines. The Pulse Asia survey firm reported that President Rodrigo Duterte's approval and trust ratings surged in December 2019. The latest public approval figure for the Philippines' chief executive is at $87 \%$, or 9 percentage points higher than September's $78 \%$. His trust rating, meanwhile, is at $83 \%$ or 8 points higher than September. These findings were echoed by the Social Weather Stations (sws) a few weeks later (Rappler, 21 December 2019, 21 January 2020).

22 A high 79 percent of Filipinos said they were satisfied with the campaign vs illegal drugs, and net satisfaction with the anti-illegal drugs campaign has always been either very good $(+50$ to +69$)$ or excellent $(+70$ and above) in the past 12 survey rounds. The campaign recorded its highest satisfaction rating at the outset of the Duterte administration, or in December 2016 with an excellent +77 . Ironically, the same survey said that while people had very high satisfaction ratings, $76 \%$ of Filipinos also saw many human rights abuses in the administration's war on illegal drugs (Social Weather Stations, 15 January 2020). 
Some media organizations have lent credence to reports that the drug menace has indeed become weaker, an observation that is not borne out by the facts. ${ }^{23}$ An objective external analysis conducted by a well-known US thinktank, the RAND Corporation, of the Philippines government's campaign against illicit drugs noted that the metrics for claiming "success" were vague and ineffective, i. e., "it is unclear what consideration has been made to measures of success or to the opportunity costs of utilizing scarce public security and health resources", and "there seems to be no official effort to evaluate these policies in terms of their effectiveness or harms caused". ${ }^{24}$

The Philippine Vice President Maria Leonor "Leni" Robredo herself pinned the blame on law enforcers who were only neutralizing low-level pushers instead of cutting off their sources and recommended a shift in targeting from the demand side towards the supply side. The failure to adequately address the supply side is evidenced by the underground market for illicit drugs that continues to provide affordable prices that enable the poor to use, buy, and sell crystal meth or shabu, cocaine, marijuana, ecstasy and other drugs.

The country's methamphetamine (shabu) retail price has continued to fluctuate during the previous and current administration, indicating the resilience of the illicit drug trade in the country. In 2010 the price of shabu was much higher at Philippine pesos 9,745 (\$191) per gram. However, following a series of arrests and the seizures of narcotics in 2015 under the Aquino administration, prices went down to 9,000 $\mathrm{PhP}$ ( $\$ 180$ ) per gram instead of going up. ${ }^{25}$ A few months before the national elections that would put Duterte in the presidency, prices collapsed to 1,000 PhP (\$19) per gram due to the intense competition among the Chinese, African and Mexican drug rings. ${ }^{26}$

Prices would double under the new government following the launch of its war on drugs, reaching 3,500 $\mathrm{PhP}(\$ 68)$ per gram in the National

23 The Economist, 20 February 2020.

24 Philippine Daily Inquirer, 31 July 2019.

25 Business Mirror, 29 July 2015.

26 United Nations Office on Drugs and Crime, n. d. See also Business Mirror, 29 July 2015. 
Capital Region (NCR). However, prices would slump again two years later to $1,200 \mathrm{PhP}(\$ 23)$ per gram in 2019 , after more than 1.6 tons of crystal meth were discovered to have been illegally imported into the Philippines in late 2018. During this entire period, the steepest prices for illegal drugs across the country could only be found in the President's hometown of Davao City where shabu sold at 11,000 PhP (\$215) per gram, underlying how important Davao was to the credibility of the President's campaign. ${ }^{27}$

In 2019 the United Nations Office on Drugs and Crime (UNODC) acknowledged the significant decline in seizures of selected drugs and precursor chemicals such as crystalline methamphetamine in the Philippines since the beginning of the Duterte administration in 2016. However, the agency also reported opposite results for illegal drugs other than crystal meth, exposing the spike in seizures of liquid methamphetamine, ecstasy pills, and cocaine (table 1).

Table 1. Seizures of selected drugs and precursor chemicals in the Philippines, 2013-18

\begin{tabular}{|l|c|c|c|c|c|c|c|}
\hline \multicolumn{1}{|c|}{ Drug type } & Unit & 2013 & 2014 & 2015 & 2016 & 2017 & 2018 \\
\hline $\begin{array}{l}\text { Crystalline } \\
\text { methamphethamine }\end{array}$ & $\mathrm{kg}$ & 837.6 & 718.5 & 595.8 & $2,210.5$ & $1,053.9$ & 785.8 \\
\hline $\begin{array}{l}\text { Liquid } \\
\text { methamphethamine }\end{array}$ & $\mathrm{It}$ & 0 & 17.6 & 0 & $1,805.7$ & 50.2 & 110.8 \\
\hline “Ecstasy" & tablets & 52 & 3,599 & 2,902 & 21,736 & 591 & 16,713 \\
\hline Berzodoazepine & tablets & 20 & 216 & 2,304 & 120 & 83 & 876 \\
\hline Cannabis herb & $\mathrm{kg}$ & $1,391.3$ & 799.6 & $1,032.4$ & $1,334.6$ & 431.7 & 256.1 \\
\hline Heroin & $\mathrm{kg}$ & 12.2 & 69.9 & 11.5 & 70.6 & 9.9 & 94.6 \\
\hline GHB & $\mathrm{It}$ & $\bullet$ & $\bullet$ & 3.1 & $\bullet$ & 0 & $\bullet$ \\
\hline Pseudophedrine & $\mathrm{kg}$ & $\bullet$ & $\bullet$ & 2.11 & $\bullet$ & 209.5 & 0 \\
\hline Ephedrine & $\mathrm{kg}$ & 0.6 & 510.1 & 49.8 & 9.9 & 0.02 & 0.5 \\
\hline
\end{tabular}

Note: $\cdot=$ not reported

Souerces: DAINAP; UNODC ARQ 2017 and previous years for the Philippines; Official communication with DOB, February 2019.

27 Philippine Daily Inquirer, 31 January 2019. 
UNODC also reported the steep rise in the number of drug-related arrests in the Philippines, primarily due to intensified law enforcement activities focused on methamphetamine. Despite the heightened law enforcement measures however, the seizure of large-scale illicit methamphetamine manufacturing facilities, as well as trafficking involved with several hundred kilos of the drug, has been continuously reported in recent years.

In 2019, the government reported that a thousand kilograms $(\mathrm{kg})$ of shabu worth $\mathrm{PhP} 6.9$ billion slipped past the hands of authorities despite the coordinated efforts of its biggest anti-illegal drugs agencies such as the Philippine National Police (PNP), the Philippine Drug Enforcement Agency (PDEA), and the Bureau of Customs (BOC). Authorities also revealed that the Philippines had become a trans-shipment point for other dangerous drugs such as heroin and cocaine. The PDEA reported the entry of a new regional crime gang called the Golden Triangle Syndicate that was behind the huge shipment that was believed to have come from Taiwan and China. ${ }^{28}$

Finally, the UNODC noted how the country has been increasingly targeted for trafficking of cocaine by sea, and relatively large quantities of the drug have been seized in recent years. National authorities have also observed the increasing availability of liquid ecstasy in the country. The table below shows how the increasing volume of new drugs flooding the market is hidden in a study of trends in the use of selected drugs.

Table 2. Trends in use of selected drugs in the Philippines, 2013-2017

\begin{tabular}{|l|c|c|c|c|c|}
\hline \multicolumn{1}{|c|}{ Drug type } & 2013 & 2014 & 2015 & 2016 & 2017 \\
\hline Crystalline methamphethamine & $\uparrow$ & $\uparrow$ & $\uparrow$ & $\uparrow$ & $\downarrow$ \\
\hline Berzodoazepine & $\downarrow$ & $\uparrow$ & $\downarrow$ & $\uparrow$ & $\downarrow$ \\
\hline Cannabis herb & $\downarrow$ & $\uparrow$ & $\downarrow$ & $\uparrow$ & $\downarrow$ \\
\hline Inhalants & $\downarrow$ & $\downarrow$ & $\downarrow$ & $\downarrow$ & $\downarrow$ \\
\hline
\end{tabular}

Note: *Based on expert perception provided by the Dangerous Drug Board (DDB).

$\uparrow=$ Increasing, $\downarrow=$ Decreasing, $\leftrightarrow=$ Stable $\cdot=$ Not reported.

Source(s): Drug Abuse Information Network for Asia and the Pacific (DAINAP); UNODC Annual Report Questionnaire (ARQ) 2017 and previous for the Philippines; Official communication with the Dangerous Drugs Board (DDB). October 2018.

28 Rappler, 10 August 2018. 
The data shows a decrease in the use of selected drugs in the UNODC table, such as crystal meth, benzodiazepine, cannabis, and inhalants in 2017, but does not include the increase in the use and seizures of cocaine, ecstasy, and other drugs enumerated in table 1 that were registered from 2013 to 2017 (table 2).

The turn-around from periods of dramatic reduction in the production and trade of illicit drugs to sudden spikes in supply and a collapse in prices is not unheard of in the rest of Southeast Asia. Thailand is a good comparator. Despite the efforts by the Thaksin administration, drug consumption - especially methamphetamine- ultimately returned to an alarming level. The number of meth labs in Thailand, for instance, went from 2 labs between 2008 and 2010 to 193 between 2011 and 2012, and the Office of Narcotics Control Board of Thailand seized up to 1,140 kilos of crystal methamphetamine and 9,570 kilos of methamphetamine tablets in 2015 alone. $^{29}$

These figures presaged the final collapse of Thaksin's anti-drug campaign. Thaksin's government was unable to deal a significant blow to the illicit drug network - as the major Thai drug lords escaped capture and cross-border trafficking continued along the profitable drug routes from Myanmar that were protected by corrupt officials across the two borders-.

\section{Social networks and the illicit drug economy in the metropolis}

When the Philippine Drug Enforcement Agency was established in 2002, the major criminal gangs in the northern and central part of the Philippines were those in control of the shadow economy in illicit drugs. Six years before Duterte became president, the government outlined three critical issues: the intensification in the manufacture of crystal methamphetamine in urban and peri-urban areas; the cultivation of marijuana in the upland provinces mostly in the Cordillera regions;

29 PhilRights, 12 September 2018. 
and the trafficking of illicit drugs across borders by Filipino "mules" and international syndicates (Cagoco-Guiam \& Schoofs, 2016, p. 121).

This was the period when criminal and trafficking gangs, some of them located in the national prisons and correctional institutions, were busy consolidating and expanding production and trading networks for drugs and the hiring and deployment of mules for domestic and international routes. ${ }^{30}$ Outside of prison the manufacturing hubs grew out of middle-class subdivisions while the wholesale and retail marketing of illegal drugs was concentrated within informal settler communities.

Informal settlements became the locus of drug use and trade because they were the also the centre of activity and the residence of out-ofschool youth and the other underemployed or seasonally-employed men and women who were the most numerous consumers of shabu and marijuana. Studies have shown how a large proportion of urban poor youth who were engaged in exhausting livelihoods and jobs with unusually long hours were compelled to use drugs such as shabu to cope and stay awake (Fuertes-Knight, 2017). ${ }^{31}$

Many communities became the sites of the drugs "tiangge" or dwelling-places established by street dealers where you could swiftly and conveniently consume the drug in the private company of other addicts. $^{32}$ The tiangge were often serviced by tricycles that ferried customers in and out of the informal settlements.

These tricycles are a regular feature in many urban areas and an intoxicating presence, due to their dirty fumes and the loud noise from their exhaust pipes. They careen back and forth into the small streets that snake into the armpits of Manila urban poor communities. Their drivers and operators are organized into associations called the TODA, and they often traffic and control the ingress and egress of people and goods in urban poor colonies and enclaves in the metropolis.

More importantly, they are a strategic social network that criminal gangs and drug syndicates have tried to control so as to achieve the

30 Interview with a former prisoner in the national penitentiary. Name and date withheld.

31 The report in The Guardian (2 February 2017) noted that jobs in the entertainment, transport, and logistics companies were hubs for the massive use of crystal meth and cocaine.

32 Social networking among addicts and pushers grew out of these tiangges, which later became beer joints and hubs of prostitution. 
smooth entry of illicit goods such as illicit drugs and weapons into these enclaves. They are certainly a strategic and reliable source of information and a useful logistic instrument for economic, political, or social activities.

Sometimes the "shadow authorities" succeed in controlling the TODA, but oftentimes they do not. Because of its inherent power and broadbased constituency, this social network thrives best when it remains autonomous from criminal groups, local elite groups and middle-class organizations. They cannot be easily mobilized without a process of bargaining and social contracting with its leaders and members. "In our city the TODA functions as an important mobilizing instrument for vote banks and can determine the fate of elected officials. They bring voters to the election booth and they are relied upon as emergency responders in times of natural or man-made calamities, from fires, typhoons, to gang wars. They are the sinews of local norms and rules that every service provider must follow - honesty, cordiality, reliability, and most important of all, confidentiality-".33

Prior to the widespread entry of illicit commodities such as drugs, the informal tricycle transport economy functioned as an unregulated and untaxed occupation that provided a basic livelihood for hundreds of thousands of Manila's urban poor youth. They could be mobilized for campaigns against illicit economies and can make life difficult for the criminal gangs that want to bring in illegal drugs into the local economy. Drug cartels will try their utmost to control the TODA or broker financial arrangements with the association to acquire their services.

The social networks that arose from the drug "tiangge" and their TODA partners constituted an important layer of support, or opposition to the functioning of illicit drug economies in Metro-Manila and other urban centres. The more intrepid and criminally inclined TODA groups would use the opportunity to create a social network of drug-dependent youth that could be harnessed for criminal activities. In other cases, the TODA groups would extract vulnerable youth away from the tiangge and

33 Interview with a national legislator whose district included a large, poor, and conflict-ridden enclave in Metro-Manila. Name and date withheld. 
create networks of support where jobs were located, credit was extended, and protection from law enforcers was secured. ${ }^{34}$

Most of the latter types preferred to remain quiet and avoid getting into confrontations with the TODA groups that were intertwined with the illicit drug economy. Consequently, their peaceful coexistence provoked an image of a peaceful but dangerous informal economy. These were the years preceding the Duterte presidency when violent conflict in this illicit economy was down and a stable peace in a usually deadly enterprise existed across the country. ${ }^{35}$

However, the launch of a more vigorous and continued attack against illicit drugs by the Duterte government, plus the eruption of violent disputes between drug lords with separate connections to the central state brought them out into the open. The turf war exploded within the urban poor areas and also inside the prisons where rival groups engaged in a proxy war to advance or retard the criminal interests of the big drug lords, some of whom were killed in these wars.

The intensification of the anti-drug campaign eventually led to the conscription of social networks affected by the illicit drug economy to support of the violent anti-drug campaigns launched by the Duterte government. These explain why in the highly urbanized metropolis of Metro-Manila, rival social networks disengaged from the illicit drug trade have organized "a surveillance system in the community, where some community members operate as 'watch dogs' who report any misconduct about drugs to the police, because they believe it will clean up their community". ${ }^{36}$

34 Interview with a ranking police officer in the central Visayas. Name and date withheld.

35 The Conflict Alert 2014 and 2015 reports showed the very low number of violent incidents in the illegal drugs economy. The spike in violent incidents in the second half of 2016 was clearly the result of the aggressive campaign launched by the government, rather than due to turf wars between drug lords.

36 A joint study by the Balay Rehabilitation Centre (Philippines) and the Danish Institute Against Torture for the Global Alliance (DIGNITY) found out that indigenous social networks at the barangay level in Barangay Silang have even cooperated with the police to root out illegal drugs (2017, p. 12). 


\section{Social network wars in the illicit drug economy in the metropolis}

A young man was gunned down early in the evening of December 2016 in a dense Muslim enclave in one of the bustling metropolises of the Philippines. His name was Ali. ${ }^{37}$ That night, he was sitting with his friends on a basketball court near the Madrasah, waiting for his young daughter who was buying a treat in one of the small 'sari-sari' ${ }^{38}$ stores in the compound.

It was just right after Salat al-'isha, the Islamic prayer between sunset and midnight. The basketball court is a common space for some 15,000 or more residents in this crowded 4.9-hectare piece of land where ethnic Maguindanaons, Tausugs, Maranaos, Yakans, and Iranon tribes live, many of whom have fled from the violent conflict of their hometown in Muslim Mindanao. The land where the compound stood was purchased in the 1970s through a grant from former Libyan strongman Moammer Khaddafy who had sponsored a peace agreement between the Philippine government and the Moro National Liberation Front (MNLF).

Ali received a fatal shot in the head that was witnessed by his young daughter along with everyone else in that stunned, crowded space. The incident was the fourth in a series of bloody events in their community, two of which were the alleged killing of drug suspects included in the "narco-list" of the barangay. ${ }^{39}$

It is easy to infer that the killing of Ali was also a drug-related incident unleashed by president Duterte's drug war, which went on full force when he took office in June 2016. This enclave, after all, is known to be a major hotspot for the illicit drugs and weapons trade in the metropolis. Ali, however, was not an enemy, but an autonomous conscript in the war against drugs, and he was slain ostensibly because he was suspected of having had a role in the creation of the narco-list in the first place.

37 Not his real name.

38 A ubiquitous neighbourhood sundry store common in most Filipino communities. It holds an important economic and social function, especially in poor and lower middle-class communities.

39 Translation: village, the smallest local government unit in the Philippines. 
The story of Ali however depicts the multiple layers of the ethnic/ identity, political, and economic issues that came to the fore because of the war on drugs. Ali was a Maguindanaon and an officer of the tricycle operators and driver's association (TODA) in the compound. ${ }^{40} \mathrm{He}$ was also the head of the youth group organized by the Moro Islamic Liberation Front (MILF), a non-state armed group who forged a political settlement with the government in 2014 and were organizing political support from the cities of Metro Manila to troop to Congress for the passage of the Bangsamoro Organic Law. Control over the leadership in the compound was historically marked by brutal contestations, with intense fights for the prime leadership roles of head of the compound and head of the TODA. One can effectively control the economic, political, and social life of the compound if one is the leader of either of these two groups or both. Rents from the various enterprises and trades inside the community go through this leadership.

Tricycles represent the community's lifeblood -it carries not just passengers in that area-; it is also, figuratively, a vehicle for information and intelligence, for illicit trade, for transactions between corrupt government officials represented by the rents paid monthly to these officials to allow the drivers to ply the highway outside, and overall, a participant observer of the everyday life of the compound. It is literally, the eyes, the ears, and the pocket of the community.

There are two factions within the mainly Sulu-based Tausug tribe that have been at war for years. During that period, the incumbent Chairperson of the compound was from the faction perceived by people as corrupt and brutal, while the head of the TODA, on the other hand, was from the other faction who has strong links to the major families of the Maguindanaon tribe in the community and to civil society groups linked to development and peacebuilding projects that initiated smallscale projects in the compound. This latter group was becoming a strong contender for the leadership of the community and posed a threat to the interests of the incumbent power holder who had already lost two

40 Or a 'trike', a three-wheeled public utility vehicle consisting of a motorcycle and an attached passenger's side car. This is the second most popular public transportation in the Philippines next to jeepneys. 
top henchmen in the drug war. The leadership at that time suspected the other group to be working with the police and the military, instrumentalizing the drug war to weaken them for a take-over.

The killing of Ali unleashed a string of violence that culminated in a community shoot-out between the two warring groups. This time, a Maguindanaon leader took revenge for the death of Ali and held the community hostage, fighting the police and military who went in to intervene.

This was the first time in the history of this community, and since the compound was established in 1971, that they had experienced collective violence of this sort. The eruption of criminal and ethnic violence within the enclave was widely different from the collective violence that engaged their forebears. The compound had a history of collective resistance and was the fruit of the labour of the first leaders under the Islamic Directorate who were the anti-Marcos activists from Muslim Mindanao and who later fled back to the South or to the Middle East when Marcos declared martial law in 1972.

There has been a change in leadership since the events of 2016. People say it has only been from 2019 that the tension and the volatility of the situation in their compound has finally stabilized. They say they can now feel government with welfare provisions reaching their compound as compared to before. It does not matter that they have lost a good part of their income without the auxiliary benefits of the illicit trade in their area; what matters, they say, is that they finally feel secure and unafraid. There are sectoral organizations flourishing -women's groups forming welfare networks-, and Ali's youth group is now thinking of organizing again.

The leadership of the TODA went to the Maguindanaon leader who was recently released from detention for his alleged involvement in the December 2016 violence. He belonged to Ali's faction. The Chairperson of the compound is a respected Sultan who was among the original signatories in the land title possessed by the Islamic Directorate for the parcel of land donated by Libya.

There is relative peace in the compound and people remain strong supporters of Duterte. They perceive the events of 2016 as an opening to finally get their community out of the stigma of illegality, lawlessness, and 
violence. But when asked if they think this stability would be sustained, they respond with the kind of silence that can either represent hope for the future or the resignation that comes when political, economic, and identity-based interests are at stake, and nothing is for certain.

\section{Social networks and the illicit drug economy in Mindanao}

The rapid increase in domestic demand for shabu, plus the corresponding increase in deaths, arrests, and seizure of confiscated narcotics from 2002 to 2008 pushed the illicit drug economy to undertake evasive moves by importing from abroad. In 2017, the Philippines reported clandestine production of methamphetamine (ten labs were detected in 2016), though much of the drug supplies were now being imported from China, and with a growing amount imported from Mexico. ${ }^{41}$

The United Nations Office on Drugs and Crime (2019, p. 46) in the World Drug Report 2019 also noted the shifting regional trends regarding China in their updated report, stating that more of the methamphetamine available in East and South-East Asia was sourced in the subregion, with Myanmar and, to a lesser extent, China. Some of the methamphetamine was also sourced outside the subregion, including, in descending order, in Mexico, the United States, the Islamic Republic of Iran and India, although their role in supplying markets in East and South-East Asia remains limited. ${ }^{42}$

Since most of the crystal meth at this time was already being manufactured in Mindanao or imported from abroad, the brutal and deadly campaign being waged in the national metropolis and the other major cities of Luzon and the Visayas seemed clearly misdirected. However, the vulnerability of imported drugs to interdiction or capture meant that local production would need to continue under new conditions, specifically the downsizing of production labs and their relocation from urban to rural areas (Cagoco-Guiam \& Schoofs, 2016, p. 124). ${ }^{43}$

\footnotetext{
41 RAND Corporation, 2019. See also UNODC (2017d, p. 23).

42 United Nations Office on Drugs and Crime, June 2019.

43 Barrientos, B. GMA News Online, 12 February 2009.
} 
Consequently, the move to rural areas that were beyond the easy scope of law enforcement made Mindanao an excellent expansion area for the production and storage of shabu inside the country. It also shifted the locus of social networks attached to the illicit drugs economy towards the families, clans, and criminal gangs that were already embedded in the informal economy in Mindanao.

This shift to Mindanao was critical, as many scholars (Lara \& Schoofs, 2016; Lara \& Champain, 2009) had pointed to the embedded skills, practices, and capacities of the illicit economies in Mindanao that had roots from centuries of open and free trade across the porous borders of the Sulu Sea. They "could hardly be described as clandestine or underground economies since everyone knew about them and many people participated in transactions within these markets, including law enforcers" (Lara \& De la Rosa, 2016, p. 51).

Indeed, there were at least three important characteristics that stood out in the case of Mindanao: one, the scale of the informal, unregulated, and underground economies was larger than the formal economy; two, local governments in these areas were administratively weak, did not generate revenues, were totally dependent on state-to-state transfers in the form of internal revenue allotments, and beset by violent conflict; and three, local strongmen, political officials, and shadow authorities in these areas were rewarded with political legitimacy and authority if they allowed the spread of an informal economy (Lara \& Schoofs, 2016, pp. 311-323).

But there's the rub. Social networks in Mindanao's informal economies are also closely knit and exclusionary, and intimately bound to the institutions and dynamics of the Moro clans and the Islamic rules and practices imposed by traditional religious leaders, in contrast to the rules and processes of the Mafia-type criminal gangs in Metro-Manila and in other urban and semi-urban areas. That is so because in Mindanao, these informal economies are legitimate sources of livelihoods and jobs, enabling poor and marginalized groups to cope in the midst of economic uncertainty and hardship.

For example, studies of the illicit cross border trade across the Sulu Seas amplified the notion of a benign shadow state where public sector workers wore two hats, as enforcers on the one hand, and dealers on 
the other (Quitoriano, 2019; Villanueva, 2016). They also revealed how the smuggling of various commodities often involved public school teachers who were simply involved in coping and survival mechanisms to support their family needs and send their children to school. There are other social networks that grew out of other illicit economies that could be considered as survival or coping economies such as informal credit, unregulated transport vehicles, and secondary land markets.

However, the illegal drug trade stood out from the rest. The enterprise requires relatively smaller amounts of capital yet it generates the biggest profits compared to other shadow economies. Drugs, like money, are also fungible - they can be sold or used as currency-. Drug lords can pay other criminal entrepreneurs with crystal meth or shabu and other drugs or turn their products into cold cash and hand over the funds to greedy politicians and corrupt government executives and some to the religious groups, to be used as payment for dowry, tuition fees, blood money and the like. Cash is also preferred by rebel groups and violent extremists who claim to adhere to the Islamic prohibition against haram (evil) goods yet secure more than enough funds from the illicit drug trade for their violent activities. ${ }^{44}$

This flexibility turned the illicit drug business into a more dynamic enterprise with a wider range of users -from states and clans to criminals, rebels, and violent extremists-.

In 2017 and 2018, International Alert Philippines came up with consecutive reports that explored the ties between the illicit drug economy and violent extremism. ${ }^{45}$ The 2017 conflict monitoring report showed the clear signs of an unholy alliance between extremism and the shadow

44 The narrative is lifted from summed-up conclusions from a focus group discussion about the utility of the illicit drug economy in contrast to other underground and illegal economies. Participants included a member of the Marawi Sultanate League, a local government mayor, a provincial government executive, an ulama, and the chief executive of a Mindanao-based university. Names and date withheld.

45 Conflict Alert is a data base established by International Alert Philippines. It is a subnational conflict monitoring system that tracks the incidence, causes, and human costs of violent conflict in the Philippines. It aims to shape policymaking, development strategies, and peace building approaches by providing relevant, robust, and reliable conflict data. The data is sourced from police reports, media reports, and community-level reports and presently contains more than 30000 discrete incidents of violent conflict in the Bangsamoro region alone. 
industry in illicit guns and drugs. ${ }^{46}$ The report covered the year before the siege of Marawi. A year later, the 2018 conflict monitoring report reinforced the previous year's analysis by pointing to the exchange arrangement between ISIS-affiliated groups that provided protection in exchange for payments from local government officials engaged in the illegal drugs business. ${ }^{47}$

The report underscored the evolution of stronger ties between drug lords and rebel or extremist groups that allowed the capture of devolved authority by many politicians engaged in the production and trade of illicit narcotics. ${ }^{48}$ These arrangements allayed the fears of assassination and extra-judicial killing of local government officials with ties to illicit drugs who instead confined themselves to their bases. ${ }^{49}$

Among the victims of extra-judicial execution was the mayor of a town in Maguindanao province who had been on the government's narco-list and who had been accused of providing financial resources to the Maute extremist group and the combatants of the Moro Islamic Liberation Front (MILF) encamped within his municipality. ${ }^{50}$

Another victim was a well-known Mayor who local people described as a kind and benevolent leader who had built his reputation through acts of charity and did not hesitate to rush to the aid of other municipalities within the most dangerous conflict corridor in mainland Mindanao. His social contract with local citizens was to provide investments in livelihoods, tourism, and infrastructure and to not collect taxes. ${ }^{51}$

46 The Conflict Alert 2017 report cited the association between illicit guns and illicit drugs, e. g., "violence enabled by illegally acquired weapons such as guns and explosives intensified in the run-up to the May 9, 2016 national and local elections and as extremist groups launched attacks on government facilities. The crackdown on illegal drugs beginning in July also led to numerous firearm confiscations" (p. 17) (International Alert, 2017).

47 International Alert (2018).

48 SunStar News, 25 September 2017.

49 Interview with a rebel returnee who was deployed with the team of Dawla Islamiya leader Isnilon Hapilon during the siege of Marawi. Name and date withheld.

50 Riding-in-tandem gunmen attacked Talitay town Mayor Abdul Wahab Sabal in front of his hotel in Manila on February 11, 2020. Rappler (11 February 2020) reports that the Mayor was also linked to the 2016 Davao market blast and pointed to his links to the Maute-isis Group.

51 He was known for painting all structures, including the local mosque, in pink. 
Figure 1. Talitay and Datu Saudi Ampatuan in Maguindanao

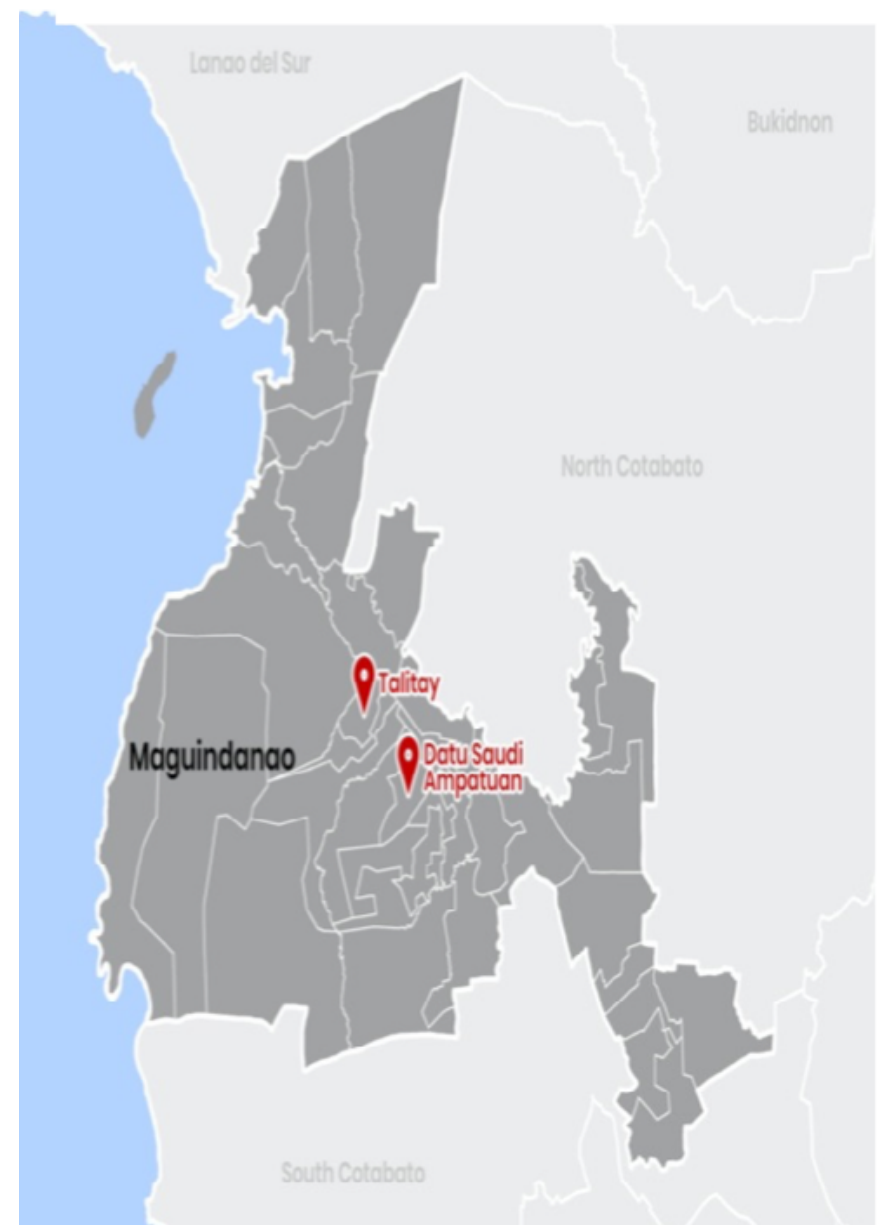

Source: PENDIENTE

In exchange he had full use of internal revenue allotments and public tolerance for his near-monopoly of the illegal drug business in the conflict-corridor. The mayor was listed in Duterte's narco-list of local government officials involved in illegal drugs and was slain together with eight of his bodyguards in an ambush. ${ }^{52}$

52 ABS-CBN News, 29 October 2016. 


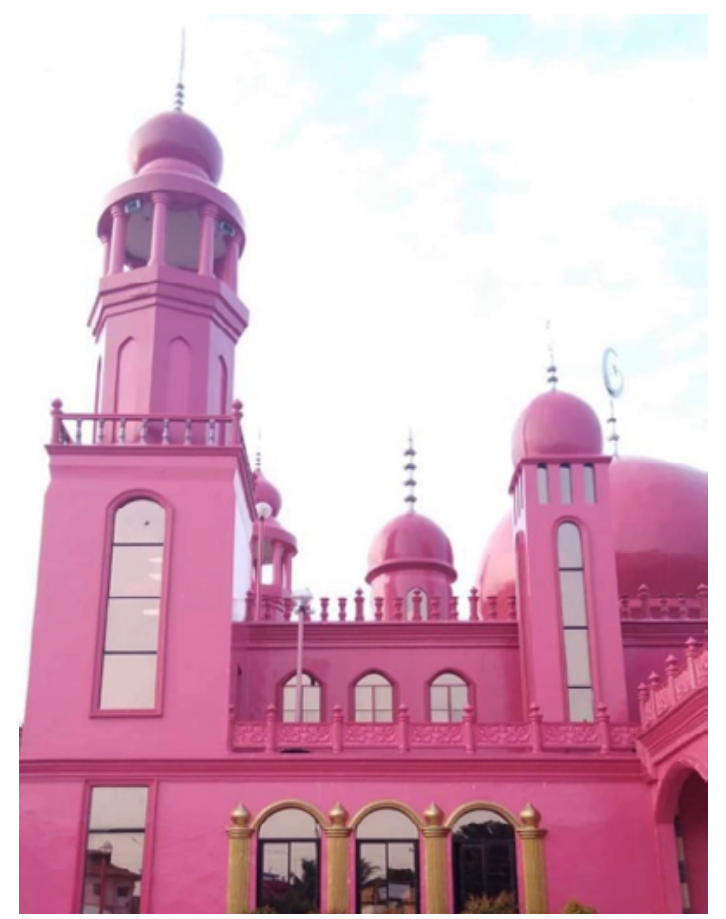

The construction of Masjid Dimakuom, or the Pink Mosque, in Datu Saudi Ampatuan, was financed by its mayor who was killed in the drug war.

As aforementioned, local strongmen such as the two mayors mentioned above are also part of a wider web of kinship relations that included families and clans laying claims to the same economic resources. A politician or a government executive are also the representatives and gatekeepers for families and clans and are thus motivated to capture and monopolize power for their clans.

Clan members became the first beneficiaries of the huge funds generated by the illegal drug trade and were also the last line of defence against any effort to disrupt their operations. In the story of the first slain mayor above, his entire municipal bureaucracies were staffed by clan members, men, women, and youth, who were involved in all stages of the production and sale of illegal drugs.

There is no doubt as well that the continuous benefits that every member of the clan received, from the most basic protection and security 
of their households to the welfare goods such as education and health care, was paid for by the illicit drug business. This is an important consideration in determining why their clans and the other social networks that they are a part of cannot prevent themselves from having a love-hate relationship with the illegal drug economy.

From illegal drugs, the clan diversified into illegal weapons and civil works projects. The same clan members were involved in the activities of the armed Moro fronts, including armed extremist groups.

For example, previous reports of the death of Sultan Saudi Ampatuan Mayor Samsudin Dimaukom only mentioned that it was due to being in the alleged "narco-list" and because he was supposedly transporting drugs through a checkpoint, but none of the reports tied it with rebel or terrorist links. Neither did the reports indicate that both also clans collided over the issue of illicit drugs, and how the alliances that the former Mayor brokered with suspected terrorist groups in exchange for protection also brought with it the spectre of illicit drugs converging with the spectre of violent extremism.

It was the subsequent killing a month later of the vice mayor who replaced the former mayor that pointed the spotlight on the former mayor's links to both the drug syndicates and other violent ideological groups. The Maguindanao police reported that several suspects in the killing of former Datu Saudi Ampatuan Vice Mayor Anwar Sindatok were members of the Moro Islamic Liberation Front (MILF) as confirmed by Von Al-Haq, spokesman for the Bangsamoro Islamic Armed Forces (BIAF), the military arm of the MILF. ${ }^{53}$

However, the rebel assassins belonged to the MILF's 118th Base Command, the largest and most militant rebel faction of the MILF based in the 2nd district of Maguindanao and led by Imam Wahid Tundok, a foreign-educated religious leader and a suspected coddler of the terrorist bombers Marwan and Usman who were both killed in 2015.54

53 The police reported that the suspects killed Sindatok because they believe he divulged to the police the location of Mayor Samsudin Dimaukom, who was killed along with nine others in a checkpoint in Makilala, North Cotabato on October 28 (The Manila Times, 30 November 2016).

54 The Manila Times, 30 November 2016. 


\section{Drugs and rebellion: the case of Marawi}

A political economy analysis of the illicit drugs enterprise in Mindanao would clearly suggest that it was brought about by a confluence of poverty, violent conflict, and weak governance (Cagoco-Guiam $\mathcal{E}$ Schoofs, 2016). This confluence is revealed by the presence and influence of drug syndicates at various levels of the state in the extremely poor and disadvantaged communities of Central Mindanao where the production and processing of crystal meth is located.

The junctions of the illegal drug trade in Mindanao are found in Marawi city in the north, Cotabato city in the south, and Zamboanga city in the western part of the BARRM. These places were the scenes of many armed clashes between police and criminal gangs, between the military and the Moro rebels, and between warring clans. Tables 3 and 4 below indicate the proliferation of drug dens and drug groups that have been neutralized by the Philippines government and most of these are in Mindanao, particularly in the newly established BARRM. Meanwhile, figure 3 below indicates that most of the BARRM is riddled with clandestine laboratories and the concentration of illicit drug smuggling incidents was reported in the city of Zamboanga and the islands of Basilan and Sulu.

Table 3. Number of neutralized drug dens in 2011, some were discovered in Cotabato, Maguindanao, and Marawi City

\begin{tabular}{|c|c|}
\hline Region & Neutralized drug dens \\
\hline ARMM & 10 \\
\hline Rest of Mindanao & 5 \\
\hline Visayas & 6 \\
\hline Luzon & 6 \\
\hline
\end{tabular}

Source: Philippine Daily Inquirer (18 June 2011).

Table 4. Geographical distribution of neutralized local drug groups, 2009-2019

\begin{tabular}{|l|c|c|}
\hline \multicolumn{1}{|c|}{ Region } & 2008 & 2009 \\
\hline NCR & 6 & 57 \\
\hline CAR & 3 & 5 \\
\hline
\end{tabular}




\begin{tabular}{|l|c|c|}
\hline \multicolumn{1}{|c|}{ Region } & 2008 & 2009 \\
\hline Rest of Luzon (Region 1-5) & 17 & 80 \\
\hline Visayas (Region 6-8) & 56 & 49 \\
\hline ARMM & 0 & 6 \\
\hline Rest of Mindanao (Region 9-13) & 6 & 51 \\
\hline Total Drug Groups Neutralized & 37 & 248 \\
\hline
\end{tabular}

Source: PDEA $(2008,2009)$.

Figure 3. Map of critical areas in Mindanao with recorded incidents from 1997-2018

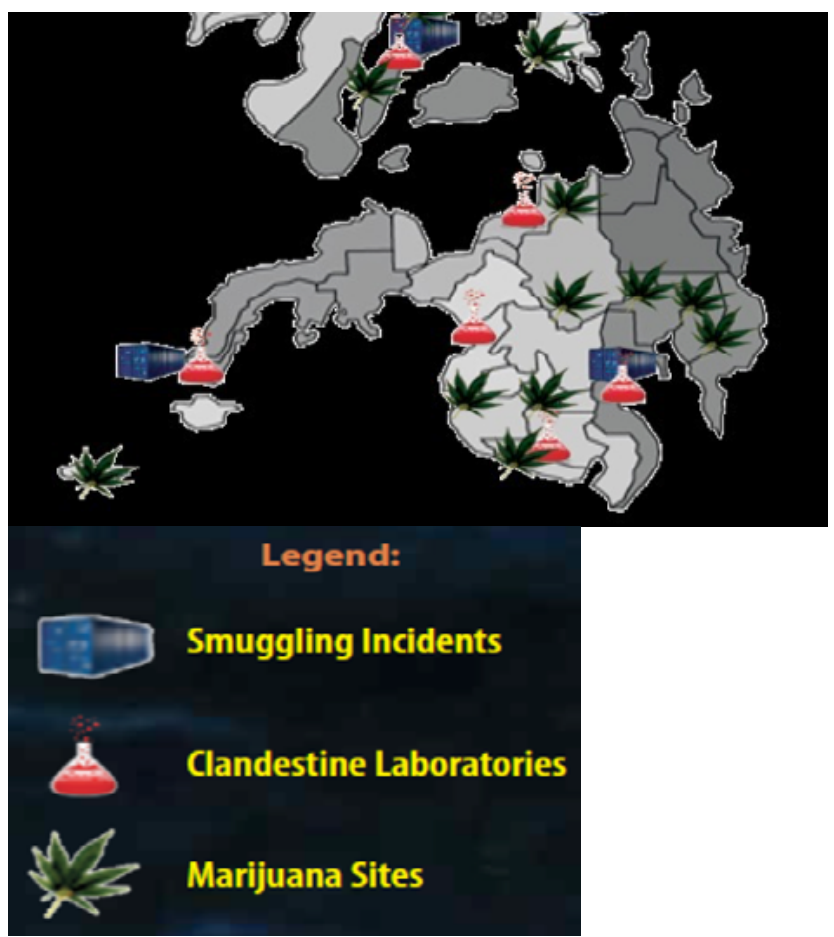

Source: PDEA 2018 Annual Report.

In the past decade, major cocaine smuggling incidents were recorded in Davao City amounting to about 85 kilograms, as well as 69 kilograms of shabu in Zamboanga City. Clandestine laboratories were discovered and dismantled in the cities of Cotabato, Cagayan de Oro, and General 
Santos. ${ }^{55}$ Meanwhile, marijuana plantations in Misamis Oriental, Bukidnon, Davao Oriental, Davao Del Norte, Compostela Valley, North and South Cotabato, Sultan Kudarat, Sarangani, and the Province Sulu were all eradicated. The extent of operations from smuggling to production to trading and the coverage across Muslim Mindanao and beyond it is a clear sign of how this illicit economy is colluding with state authorities across the island.

The situation echoes some of the characteristics of Keen's (2008, p. 7) "sell game", where contending parties often collude against state security agents and external competitors to protect the enterprise from grievous harm, and collide with each other when circumstances permit to restructure elite bargains and recast or revitalize arrangements that run from centre to periphery and top to bottom in the drug value chain. These were highlighted in the links between illegal drugs and extremist violence that exploded in the Islamic City of Marawi in 2017 (Conflict Alert, 2018).

Lanao del Sur's capital city of Marawi was in a state of siege as extremist groups took control of the city for close to eight months in 2017. While the national and international media laid their eyes on the battle by ISIS-linked militants against the Philippine government soldiers, a more subtle and almost hidden spread in drug-related incidents was happening in the province of Lanao del Sur, beginning in 2013 and spiking in 2016 or a year before the war in Marawi. The data also shows that though there was a clear decline in incident numbers after 2016, the average number of incidents was still higher than those from 2012-2015 (figures 4-5).

From 2012-2016, Marawi contributed the most to the number of drug-related incidents, a proportion that remains significant years later. Marawi City had the highest number of incidents from January to October 2019 at almost 30 incidents followed by the municipality of Wao (figure 6).

55 Manila Standard, $1^{\circ}$ October 2016; Philippine Star, 10 May 2005, 13 June 2009; MindaNews, 22 February 2014; Philippine Daily Inquirer, 22 October 2010. 
Figure 4. Number of illegal drug-related incidents,

Lanao del Sur, 2011 to October 2019

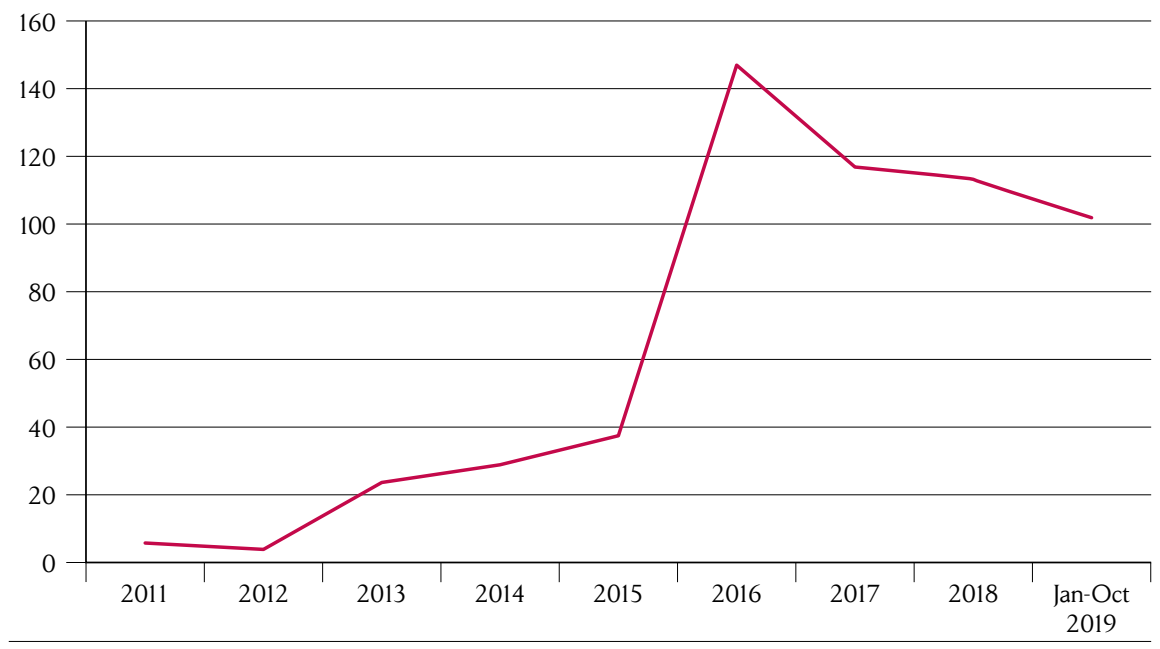

Source: International Alert (2020).

Figure 5. Number of illegal drug-related incidents by town, Lanao del Sur, January to October 2019

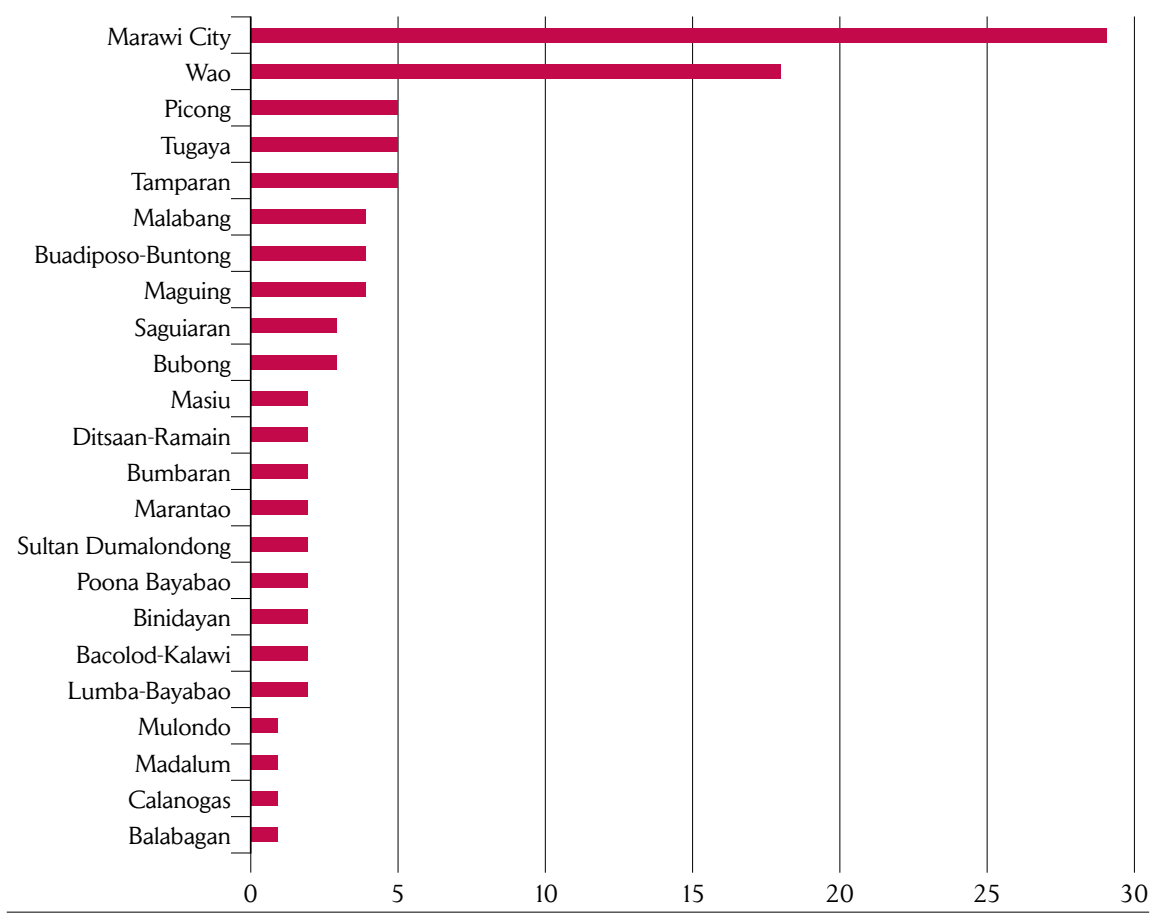

Source: International Alert Philippines (2020). 
Figure 6. Number of illegal drug-related incidents, Lanao

del Sur and Marawi City, 2011 to October 2019

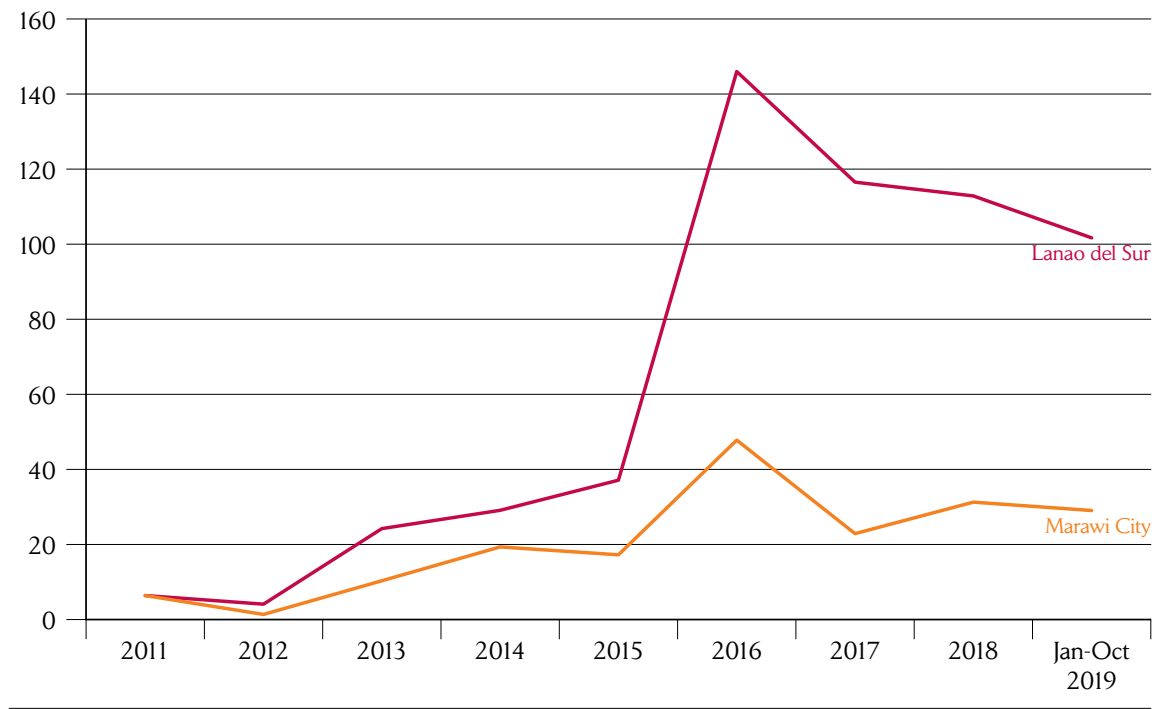

Source: International Alert Philippines (2020).

From the data one can see how Marawi city with its many drug-related incidents is an important petri-dish for observing the interlinkages between state and society on the issue of illegal drugs. However, there is another puzzle that needs to be resoved, i. e., why has the number of drug-related incidents resulted in a lower number of deaths in Marawi?

The answer lies in the convergence of clan institutions and the rule-systems that encompass the illegal drug trade. Everywhere else in the country the body-count from the war on drugs has been rising at a fast clip. This has not been the case in Lanao del Sur in general, and Marawi in particular, because clan rules about revenge killings and feuding can unleash a violent response that is greater in proportion to the human costs at the outset. In short, it is not as easy for criminal gangs or members of the police and military to wantonly kill a drug peddler in Muslim Mindanao, as they often do in Manila, without incurring a far bigger onslaught of violence. 
Figure 7. Number of illegal drug-related deaths, Lanao del Sur and Marawi City, 2011 to October 2019

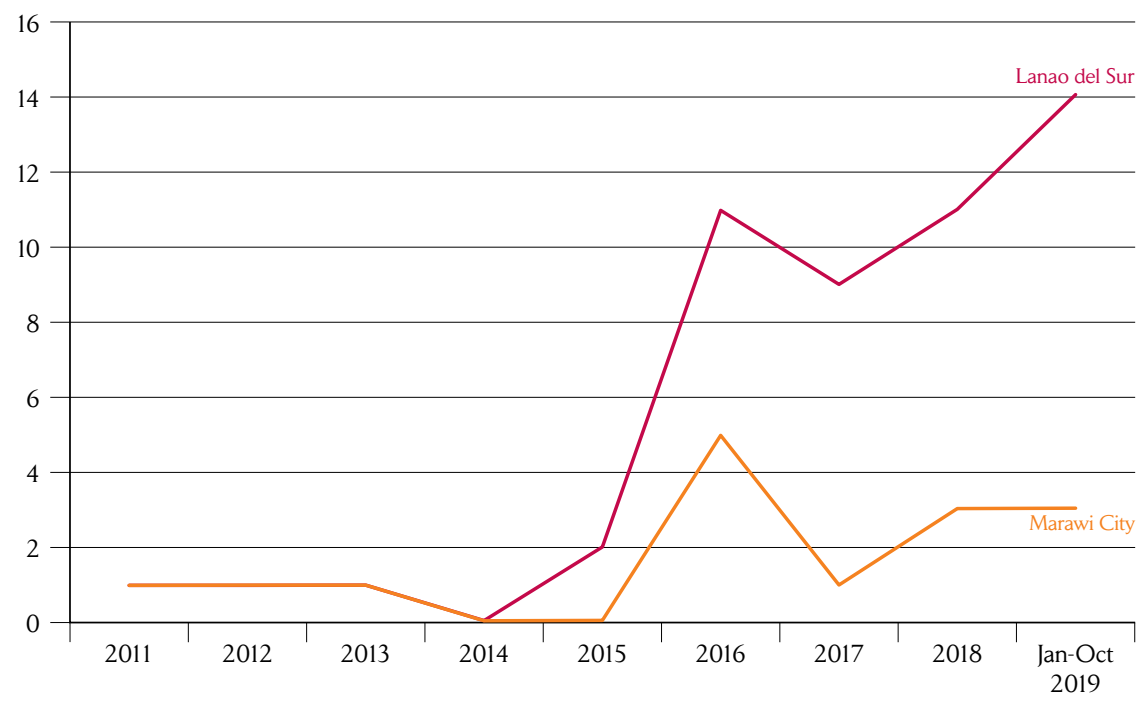

Source: International Alert Philippines (2020).

Except if you were a leading member of a clan involved in illicit drugs and you totally opposed this illicit economy and were forced to use your authority and power to destroy this economy.

This was the case in 2003 when then Marawi Mayor Omar Ali went on an all-out war against the illicit drug economy that pitted him against his close relatives, including his brother, son, and nephews. Ali, who was popularly known by his nom de guerre Solitario when he was still a military commander of the Moro National Liberation Front (MNLF), attacked the "lumber" area of Marawi near Lake Lanao with his police forces and paramilitary assets to destroy a drug tiangge in the area that led to the arrest and detention of local drug lords and the death of some of their followers. ${ }^{56}$

Ali had been under increasing pressure from the traditional and religious leaders to act against the drug lords, and being a devout Muslim, he had tried to find ways to deter the spread of harmful narcotics in the Mindanao State University (MSU) main campus in Marawi City, but to

56 Interview with an executive officer who was on the team of Omar Ali and joined the attack in the lumber area of Marawi. Name and date withheld. 
no avail. The attack followed the ambush-killing of a policeman who was also a member of a powerful Muslim clan and who had opposed the drug lords. Ali saw that the opportunity was right to launch a violent campaign because he had secured an alliance born out of frustration and grief over the deadly impact of the illicit drug economy. ${ }^{57}$

In cases where fractures in a social network intensify, there are few opportunities for patching things up without a violent interlude, especially if what is at stake is a business that generates enormous profits for just one faction of the family or clan. There is no doubt that a turf war on illegal drugs can lead to inter and intra-clan feuding, including inter-generational wars between the Moro clans that can restructure alliances and bring about a new political settlement between subnational drug lords.

It is worth noting too that a resilient "peace" had been a feature of the illegal drug economy prior to Duterte's war on drugs. Collusion had brought peace among drug lords as their turf wars ended and Mindanao, especially Lanao del Sur, became the production hub for crystal meth. However, the war on drugs launched by the State stirred the hornet's nest and sparked a collision among drug lords that coincided with the explosion of extremist violence in Marawi.

Enormous resources are needed to undertake the sort of extremist violence that saw ISIS-affiliated groups lay siege and engage in positional warfare in Marawi for five months. Contagion theorists would like to explain this newfound capacity by looking at illicit aid flows from ISIS international to the Maute group. However, there is a secondary source that is easily verifiable and more reliable as a source of funding -the funds that come from the illegal drugs economy in Lanao del Sur and the rest of Mindanao-.

The story of another local government executive in Marawi that followed the one that launched the war on drugs is illustrative, as his alleged involvement in both the illegal drug economy and the financing of the war in Marawi is the key narrative that points to the intimate relationship between collusion and collision in the war on drugs. ${ }^{58}$

57 Interview by the author with Omar Ali (MSU Marawi campus, 7 September 2007).

58 The former mayor of Marawi City, Fajad Umpar Salic, was arrested by the police on June 7, 2017, and was charged of the crime of rebellion together with Ominta Romato "Farhana" Maute, mother of the Maute leaders Abdullah and Omar that led the siege of Marawi together 
Prior to the war in Marawi the mayor was suspected of being one of the leaders of the cartel of drug producers and traders called the "Lucky 7 Group" (Cagoco-Guiam \& Schoofs, 2016). However, the growing web of ties with various extremist and criminal groups plus the open defiance and violent confrontation with law enforcers in Marawi City that led to the ambush and death of members of the security forces, including the chief of police of Marawi, was a turning point in the clan's relationship with other clans. First, this heinous act invited a politico-military response from a combined security task force that led to the war on drugs in Marawi just a year before the explosion of war in Marawi. ${ }^{59} \mathrm{Next}$, the clans started to see how the predominant clan engaged in the illicit drug economy was beginning to place in danger the other social networks involved in other aspects of Marawi's informal economies.

The marriage of illegal drug money and violent extremism provoked the collision that saw a recasting of alliances and the birth of a new political settlement that allowed the operations of the illegal drug economy so long as its ties were severed from violent extremism. Two years later, the assassination of other drug lords with links to extremist violence continued apace the increase of drug buy-bust operations after martial law was lifted in Marawi. The old actors are now in prison and the government is still running after their allies. Meanwhile, the illegal drug economy lives on and a fragile peace now exists.

\section{Conclusions}

\section{Collusion and collision within social networks}

Studies of "war against drugs" campaigns in other countries are often imbued with the narratives of fear and anxiety, fraud and corruption,

with Isnilon Hapilon. Farhana is believed to be the financier of the Maute group while Salic's name appeared among checks confiscated by the military in one of Maute group's hideouts (Philippine Star, 8 June 2017).

59 Police Superintendent and Marawi Chief of Police Al Abner Wahab Santos was driving his vehicle when he was shot dead in Barangay Luksa Datu in Marawi City on October 17, 2015. The police spokesperson lauded the police chief for his courageous fight against drug syndicates in the city (Rappler, 17 October 2015). 
and the repression and impunity that has characterized the ways in which these wars have been waged. These narratives cannot be ignored or dismissed because they hold so much truth about the marginalization, discrimination, and ruthlessness suffered by communities where social networks identified with illicit drug economies are nested. It is the reason why popular support for these violent campaigns has been described as some sort of push-back from disgruntled communities burdened by poverty and crime who now lauded the violent impunity of State and non-state actors in their communities, even if these turned them into collateral victims themselves.

This paper has raised the issue of agency and accountability in some scholarly and journalistic explanations of the war on drugs, as evidenced by the assignment of actions to an ambiguous and amorphous "public" and "community" or even to "enemies" and "dangerous others" These categories were used without any acknowledgement of the diverse choices and responses that people take to manage risks, and without a recognition of the separate tribal, clan, and class divisions in urban and peri-urban areas where the "public" is concentrated.

The weakness in determining agency is accentuated by explanations that reified the fear and anxiety that "people" felt towards illegal drugs as the basis for their acceptance of a mailed-fist approach. The autonomous and diverse actions embedded by tradition and practice among the urban and rural poor makes it clear that violent responses are not always an easy option for the poor and is neither their primary preference because of the costs they personally and physically incur. Yet this basic calculus seemed lost among the proponents of "penal populism".

Curato (2016, p. 100) reflects this view when she explained that "Duterte's anti-drug crusade recognised the public's latent anxiety and politicised a normalised issue. The populist logic of painting a dangerous 'other' gained resonance among a public that already recognised the dangerous other but did not have the confidence to name and shame the enemy, out of fear or obligation to maintain community cohesion".

Readers of such narratives will probably see some traction in the fact that "people are afraid" and that fear or social obligation leads them to applaud the repressive policies of the State. However, the actually - existing conditions in the urban poor areas of the metropolis indicates the 
opposite- people want punitive action against illicit drugs not because of an instinctive fear of violence, nor because they are seen as a dangerous other, but because they had far bigger interests and agendas that they wanted to secure and the illicit drug economy was standing in their way.

Such was the experience of the youth organization in the metropolitan enclave that fought against a social network of tribal Tausug leaders who were perceived as conspirators of the drug lords. Meanwhile, in Marawi, profits from the drug trade were finding their way into the hands of violent extremists who local people condemned for the destruction of Marawi, plus, the consumption of illicit drugs was rising among the Moro youth and pulling them away from their religious and clan obligations.

This study's approach and methodology was precisely intended to avoid such pitfalls and to bridge the gaps in previous studies. The approach leveraged the role of existing social networks and their corresponding institutional frameworks that structured their preferences and behaviours. Through this process we were able to train the spotlight on the various social networks beneath the informal economies embedded or vested in "communities". We discovered the divergent reactions from the "public" to the threat posed by the illicit drug economy. We explored the distinctive positions towards the "War on Drugs" that were taken by families and clans, religious and traditional leaders, youth and women, and Muslim and non-Muslim networks in urban, peri-urban, and rural areas.

We saw first-hand how family and clan institutions were the driving forces behind these informal and shadow economies and saw how their preferences were dissimilar to each other. Oftentimes they were allies but sometimes they were rivals. They alternately colluded or collided depending upon the contingent interests of each group. For example, there were no prior struggles against the clans in Lanao del Sur who were involved in the illicit drug economy despite the war on drugs unleashed by Duterte, but neither was there any appetite among the various Moro clans to shield the illicit drug economy or resist an anti-drugs campaign in the period before and following the eruption of extremist violence in Marawi after the so-called ISIS groups were found to have benefited from the profits generated in the shabu trade. 
A second conclusion that must be drawn is that the support for the war on drugs had less to do with individual preferences, latent fears, and the desire to instigate or prod the state to take punitive actions against the illicit drug economy, and more to do with the contingent situation and the positions taken by the social networks that people adhere to.

Decisions were not arrived at individually but were mediated within these social networks. The choices that were made were neither "fixed in stone" nor based on a set of clear and tangible rewards that were determined by the inherent interests and preferences of those networks. This explains why the production and trade in goods that are considered haram in Islam, such as drugs and narcotics, also involved social networks associated with Islamic systems and practices.

The third important conclusion is that people tend to consider a wide range of choices and time-bound responses to risks such as the entry of illicit drugs, or alternately, the risk of losing power and opportunities due to a refusal to deal in illicit drugs. Preferences are transitional and dictated by circumstances. There is no homogenous response based on inherent preferences, the only assurance being that people will take a more "substantive" response where redistribution and reciprocity matters.

To be sure, there will be struggles within social networks that lead to members swinging towards simple exchanges that do not consider the reciprocal obligations embedded within the network. This was clearly the case when the armed groups led by Wahid Tundok of the MILF exacted revenge for the death of a chief executive who was a hefty contributor to their agenda, even though he was also suspected of being involved in illicit drugs, and hence violating the Islamic admonition against illicit drugs.

There will also be instances when choices will be purely determined by reciprocity obligations with little consideration of their wider implications. This was clearly the case in the metropolitan enclave where the influence of the drug syndicate was later subdued by the social network of progressive youth located in the TODA that opposed the illicit drug trade despite the human costs that they incurred from that decision.

This was also the case in Marawi, where clan and family members colluded or collided -one faction favoured the spread of an illicit drug economy that benefitted it, while another faction resisted and opposed 
the enterprise and sought rewards that were less profitable, yet more stable and peaceful-. Instead of collisions within the network, collective and coordinated decisions within social networks to return or shift to other less destructive and deadly informal economies has always been an option for families and clans, tricycle associations, or among rebel returnees. See for example the youth network in the metropolitan enclave that prodded its members to engage in the unlicensed and unregulated transport economy instead of dealing in drugs. Their leaders explained that there were other informal economies that the youth could get involved in and besides, lobbying and advocating for the organic law that can reduce the tangible and felt discriminatory and exclusionary attitudes towards the Moro youth outside Muslim Mindanao had its own rewards. ${ }^{60}$

The fourth relevant conclusion is that the State, particularly at the local level, is not always inured to the influence of social networks in the decisions they take, or the techniques and mechanisms they employ, and there is clear evidence that the support or rejection by citizens of the State's mailed-fist formula indeed shaped the shifts in the way the war on drugs was being prosecuted. At the national level, a pause was initiated after the first 18 months of the campaign to mitigate the treatment of suspected pushers and users in urban poor communities.

At the local level, the case in Marawi and Lanao del Sur is evocative of this sensitivity and is clearly seen in the less repressive tactics and strategies that were employed in the war on drugs from the outset. The possibility of provoking a far more costly and deadlier counter-response from the Moro clans that could cripple local authority and unleash levels of violence that would be difficult to absorb demonstrates in no uncertain terms that the State can ignore clan rules and dynamics but only at its own peril.

The fifth conclusion is that the State is as important as the social networks that influence or cooperate with them or even those that denounce and oppose them, in enabling shifts to other less deadlier economies. This will not seem counter-intuitive if one looks at the State

60 Interview with another youth leader who worked with Ali and was also targeted for assassination by the drug syndicate in the enclave. Name and date withheld. 
as wearing two hats -one as an enforcer of formal rules and another as an arbiter of informal and unregulated economies that fills gaps in state provisioning-.

Bargains are made regularly between legal and shadow authorities over the informal economies that will thrive in villages and enclaves. Those bargains can lead to shifts away from drugs towards other less contentious but illicit economies such as money laundering, illicit credit schemes, illegal gambling, or the smuggling of contraband, among many others.

Sustaining and institutionalizing change, as in, forever getting rid of illicit drugs and narcotics, will require alliances and collective actions that can reel-in public authorities to support network objectives. Alternately, social networks can be made to understand and recognize the need for state autonomy from vested interests to protect its legitimacy and credibility.

The sixth important conclusion is that social networks are ubiquitous, and it is not easy to assess which among the different identities that are reflected in these social networks should be leveraged or accentuated from time to time. When we say that people support decisions and make choices based on the social networks that they adhere to, we must be aware that adhesion is not permanent. Primordial identities like gender, religion, and clan may be more "sticky" than other identities but each situation should be studied separately and carefully if we are to predict the likely attitude and behaviour that people will take.

In this paper alone, networks of families and clans, tribal groups, ulama and traditional leaders, youth organizations, trade and transport associations such as the TODA, and even ideologically-bound rebel and extremist groups carried with them varying positions and choices that could have shaped the attitude and willingness to support or resist an ongoing war against drugs. An important consideration is to recognize the multiple institutional systems that place people in "complex, often unsolvable situations, but at the same time offering them the possibility of shifting from one institutional universe to another" (Hesselbein, et al., 2006). This interplay between formal and informal institutions was an advantage, rather than a barrier in resolving problems. 
Finally, to answer the question of why there is such a wide public support for the War on Drugs from among those that are often victimized by its violence?

This paper has revealed the powerful social networks at the local level in many urban areas, as well as those located in conflict-affected rural areas, that rejected or eschewed the huge profits and other benefits offered by the illicit drug economy and saw only the differential impact of those benefits on their networks.

Some networks, such as those related to illicit weapons and kidnap-for-ransom profited from those advantages, but the vast majority of informal market activities clearly did not - such as the unregulated traffic in vehicles, boats, and motorcycles, the unregulated export of labour, informal credit markets, and even the secondary markets for land and cattle-.

One such example is the cross-border trade in Tawi-Tawi, where networks of women traders and their smuggled products were imperilled by the drug lords who used the same routes, ports, and sometimes the same vessels to transport illicit drugs, the consequence was that women traders had to absorb the same level of suspicion as well as demands for bigger pay-offs.

Some were clearly disadvantaged by the scrutiny, attention, interdiction, and repressive tactics that they had to endure resulting from the deadly outcomes in this illicit and underground activity. Some were indeed influenced by fear as well, but not because that fear invited punitive action by the State. Instead they feared that the illicit drug economy would equip a far bigger threat to their peace and security -the very real threat of violent extremism-.

There is no doubt that the continuous benefits received by members of a clan involved in illegal drugs was paid for by the illicit drug business, from the most basic protection and security of their households to the welfare goods such as education and health care, This is an important consideration in determining why local people cannot prevent themselves from having a love-hate relationship with the illegal drug economy. It also explains, however, why collusion and collision within the illicit drug economy are two alternate realities that can recur when circumstances shift and when the balance of power and opportunity in economic informality shifts to favour one sector over the other. 
Economic sociology sensitized the study to the opportunities and risks at the local level that are informed and mediated through kinship ties, clan institutions, and control over local political office. Muslim political and religious leaders have also been adept at reinterpreting religious beliefs to accommodate the survival needs of communities below. For example, the fact that Muslims consider illegal drugs as "haram" or evil yet allow their production, processing, and trade says a lot about the hybrid narratives and multiple institutions or rule systems that govern the lives of many citizens of the BARRM.

Economic sociology has also been useful in interpreting the current dilemmas faced by economic informality in the case of illicit drugs in the Philippines and particularly in Muslim Mindanao. It helped explain the logic behind people's motivations and incentives and the reality that these are based not only upon basic social norms and relationships, but also by the underlying political economy and legitimacy objectives that bind actors together to protect the illicit drugs trade, or to cause ruptures if needed.

\section{References}

\section{Books and journal articles}

Bayart, J., Ellis, S., \& Hibou, B. (1999). The criminalization of the State in Africa. Oxford: James Curry.

Cagoco-Guiam, R., \& Schoofs, S. (2016). A deadly cocktail? Illicit drugs, politics, and violent conflict in Lanao del Sur and Maguindanao. In F. Lara \& S. Schoofs (Eds.), Out of the shadows: violent conflict and the real economy of Mindanao. Quezon City: Ateneo de Manila University Press.

Cooper, F. (2001). What is the concept of globalization good for? An African historian's perspective. African Affairs, 100(399), 189-213.

Cornell, S. (2007). Narcotics and armed conflict: Interaction and implications. Studies in Conflict and Terrorism, 30(3), 207-227.

Curato, N. (2016). Politics of anxiety, politics of hope: penal populism and Duterte's rise to power. Journal of Current Southeast Asian Affairs, 35(3), 91-109. 
Duffield, M. (1998). Post-modern conflict: warlords, post-adjustment states and private protection. Civil Wars 1. London: Frank Cass Publishers.

Duffield, M. (2000). Globalization, transborder trade, and war economies. In M. Berdal \& D. Malone (Eds.), Greed and grievance: economic agendas in civil wars. Colorado: Lynne Rienner Publishers.

Goodhand, J. (2005). Frontiers and wars: the opium economy in Afghanistan. Journal of Agrarian Change, 5(2), 191-216.

Granovetter, M. (2011). Economic action and social structure: the problem of embeddedness. In M. Granovetter \& R. Swedberg (Eds.), The sociology of economic life. Boulder, Colorado: Westview Press.

Hesselbein, G., Golooba-Mutebi, F., \& Putzel, J. (2006). Economic and political foundations of State making in Africa: an understanding of State reconstruction. Crisis States Working Paper, Series 2, Nº 3.

Kaplan, R. (1994). The coming anarchy. Atlantic Monthly, 273(2), 44-76.

Keen, D. (2008). Complex emergencies. Cambridge: Polity Press.

Lara, F. (2014). Insurgents, clans, and States: political legitimacy and resurgent conflict in Muslim Mindanao, Philippines. Quezon City: Ateneo de Manila University Press.

Lara, F. (2016). The shadow economy and strongman rule in Mindanao. In P. Hutchcroft (Ed.), Mindanao: the long journey to peace and prosperity. Mandaluyong: Anvil Publishing.

Lara, F., E Champain, P. (2009). Inclusive peace in Muslim Mindanao: revisiting the dynamics of conflict and exclusion. London: International Alert.

Lara, F., E De la Rosa, N. P. C. (2016). Robustness in data and methods: scoping the real economy of Mindanao. In F. Lara E S. Schoofs (Eds.), Out of the shadows: violent conflict and the real economy of Mindanao. Quezon City: Ateneo de Manila University Press.

Lara, F., E Schoofs, S. (Eds.). (2016). Out of the shadows: violent conflict and the real economy of Mindanao. Quezon City: Ateneo de Manila University Press.

MacGaffey, J. (1991). The real economy of Zaire: the contribution of smuggling and other unofficial activities to national wealth. Philadelphia: University of Pennsylvania Press.

Meagher, K. (2010). Identity economics: social networks and the informal economy in Nigeria. Suffock: James Currey Ltd.

Nohria, N. (1992). Is a network perspective a useful way of studying organizations? In N. Nohria \& R. G. Eccles (Eds.), Networks and organizations: structure, form, and action. Boston: Harvard Business School Press. 
Polanyi, K. (2011). The economy as instituted process. In M. Granovetter \& R. Swedberg (Eds.), The sociology of economic life. Boulder: Westview Press.

Portes, A. (2010). Economic sociology: a systematic inquiry. Princeton: Princeton University Press.

Putzel, J. (28 August 2016). Can Duterte 'populism' bring lasting peace, development? Philippine Daily Inquirer.

Quitoriano, E. (2019). From "canton goods" and rebellion to piracy and violent extremism. Unpublished manuscript.

Reno, W. (1999). Warlord politics and African States. London: Lynne Rienner Publishers.

Reno, W. (2004). Order and commerce in turbulent areas: $19^{\text {th }}$ century lessons, $21^{\text {st }}$ century practice. Third World Quarterly, 25(4), 607-625.

Simangan, D. (2017). Is the Philippines 'war on drugs' an act of genocide? Journal of Genocide Research, 20(1), pp. 68-89.

Thompson, M. R. (2016). Bloodied democracy: Duterte and the death of liberal reformism in the Philippines. Journal of Current Southeast Asian Affairs, 3, 39-68.

Villanueva, S. (2016). Cross-border illicit trade in Sulu and Tawi-Tawi: the coexistence of economic agendas and violent conflict. In F. Lara \& S. Schoofs (Eds.), Out of the shadows: violent conflict and the real economy of Mindanao. Quezon City: Ateneo de Manila University Press.

\section{News and other reports}

(10 May 2005). Cagayan de Oro shabu laboratory busted. Philippine Star.

$\left(1^{\circ}\right.$ February 2008). Most of those killed in war on drug not involved in drug. The Nation.

(22 February 2014). Hunt on for 2 escaped drug pushers in Davao raid. MindaNews.

(17 October 2015). Marawi police chief shot dead. Rappler.

(8 June 2017). Ex-mayor tagged as Maute financier. Philippine Star.

(21 December 2019). Pulse Asia: Duterte's approval, trust ratings surge in December 2019. Rappler.

(11 February 2020). Maguindanao town mayor gunned down in Manila. Rappler. (20 February 2020). Rodrigo Duterte's lawless war on drugs is wildly popular. The Economist. 
Acosta, J. (29 October 2016). Mayor Dimaukom a big loss to peace and development: LGU staff. ABS-CBN News.

Amnesty International UK. (12 January 2018). More than 7,000 killed in the Philippines in six months, as president encourages murder.

Arguillas, C. (11 February 2019). Bangsamoro is ARMM + Cotabato City + 63 villages in North Cotabato. MindaNews.

Arugay, A., E Sombatpoonsiri, J. (29 September 2016). Duterte's war on drugs: bitter lessons from Thailand's failed campaign. The Conversation.

Bergonia, T. (31 July 2019). Top US think tank sees no gauge of success in $\mathrm{PH}$ drug war. Philippine Daily Inquirer.

Cabato, R. (23 October 2019). Thousands dead. Police accused of criminal acts. Yet Duterte's drug war is wildly popular. The Washington Post.

Delizo, M. J. (18 June 2019). Over 6,000 killed in nearly 3 years of PH drug war: PNP. ABS-CBN News.

Elemia, C. (21 February 2018). Trillanes calls on Senate to defend De Lima, press freedom, right to life. Rappler.

Felipe, C. S. (8 May 2018). PNP bares numbers: 4,251 dead in drug war. Philippine Star.

Fuertes-Knight, J. (2 February 2017). The Philippines can't fight its meth battle until it wins the war on corruption. The Guardian.

Gita, R. A. (25 September 2017). Palace: Duterte has 'plan in mind' vs. narco-politicians in Marawi rebellion. SunStar News.

International Alert. (2017). Conflict alert 2017: Guns, drugs, and extremism. Bangsamoro's new wars.

International Alert. (2018). Conflict alert 2018: War and identity.

International Alert. (2020). Conflict alert data 2011-2019: Bangsamoro Autonomous Region in Muslim Mindanao [comma separated value (CSV) file].

International Drug Policy Consortium. (19 February 2019). 10 years of drug policy in Asia: how far have we come? A civil society shadow report.

Jannaral, J. (30 November 2016). Suspects in Maguindanao vice mayor murder known. The Manila Times.

Kine, P. (7 September 2017). Philippine president Rodrigo Duterte's 'war on drugs'. Human Rights Watch.

Lema, K., E Mogato, M. (16 August 2017). Philippine police kills 32 in drugs war's bloodiest day. Reuters.

Marquez, C. (31 January 2019). Average price of shabu in Metro now P3,500 per gram. Philippine Daily Inquirer. 
Morales, N. J. (16 October 2017). Philippine survey shows big support for Duterte's drugs war. Reuters.

Pardo, B., et al. (2019). Contemporary Asian Drug Policy: Insights and Opportunities for Change. RAND Corporation.

Philippine Drug Enforcement Agency. (2008, 2009). Annual report 2008 to 2009. Philippine Drug Enforcement Agency. (2018). Annual report 2018.

Punongbayan, M. (13 June 2009). Busted Cotabato City laboratory could produce 3 kilos of shabu daily. Philippine Star.

Reyes, R. A. G. (1 May 2018). How many Chinese or Chinese-Filipino drug lords have been neutralized by the PNP since July $1^{\circ}, 2016$ ? The Manila Times.

Rungsrithananon, N. (12 September 2018). Lessons unlearned: Thailand's failed war on drugs and why the Philippines is doomed to repeat it. PhilRights.

Samson, O. (29 July 2015). Shabu price drops as competition among drug gangs intensifies - PNP. Business Mirror.

Social Weather Stations. (15 January 2020). Fourth Quarter 2019 Social Weather Survey: $76 \%$ of Filipinos see many human rights abuses in the administration's war on illegal drugs, $24 \%$ see few.

Stoicescu, C., E Lasco, G. (23 February 2019). Has the decade-old war on drugs in Asia succeeded? Al Jazeera.

Talabong, R. (10 August 2018). PNP, PDEA, customs fail to stop 1,000 kilos of shabu entering PH. Rappler.

Tomacruz, S. (21 January 2020). Duterte's satisfaction rating reaches new record-high. Rappler.

Tubeza, P. C. (28 February 2017). Bato: 'Neutralization' means arrest. Philippine Daily Inquirer.

Tuyay, F. ( $1^{\circ}$ October 2016). Chinese drug lord convicted. Manila Standard.

United Nations Office on Drugs and Crime. (June 2019). World drug report 2019.

United Nations Office on Drugs and Crime. (March 2019). Synthetic drugs in East and South-East Asia: trends and patterns of amphetamine-type stimulants and new psychoactive substances.

United Nations Office on Drugs and Crime. (n. d.). Methamphetamine: retail and wholesale prices and purity levels, by drug, region and country or territory.

Yap, D. (18 June 2011). 10th drug den in ARMM neutralized - PDEA. Philippine Daily Inquirer.

Zonio, A. (22 October 2010). Narcs raid $1^{\text {st }}$ shabu lab found in GenSan. Philippine Daily Inquirer. 